\title{
Evaluation of Biological Data, Guanella Pass Area, Clear Creek and Park Counties, Colorado, Water Years 1995-97
}

U.S. GEOLOGICAL SURVEY

Open-File Report 00-54

Prepared in cooperation with the FEDERAL HIGHWAY ADMINISTRATION 


\section{Evaluation of Biological Data, Guanella Pass Area, Clear Creek and Park Counties, Colorado, Water Years 1995-97}

By Jennifer R. Cox-Lillis

U.S. GEOLOGICAL SURVEY

Open-File Report 00-54

Prepared in cooperation with the FEDERAL HIGHWAY ADMINISTRATION 

COLORADO, WATER YEARS 1995-97 


\title{
U.S. DEPARTMENT OF THE INTERIOR BRUCE BABBITT, Secretary
}

\author{
U.S. GEOLOGICAL SURVEY
}

Charles G. Groat, Director

The use of firm, trade, and brand names in this report is for identification purposes only and does not constitute endorsement by the U.S. Geological Survey.

For additional information write to:

District Chief

U.S. Geological Survey

Box 25046, Mail Stop 415

Denver Federal Center

Denver, CO 80225-0046
Copies of this report can be purchased from:

U.S. Geological Survey

Information Services

Box 25286

Federal Center

Denver, CO 80225 
Cover photograph: The Sawtooth and Mount Bierstadt, from Guanella Pass Road, Clear Creek County, Colorado. 


\section{CONTENTS}

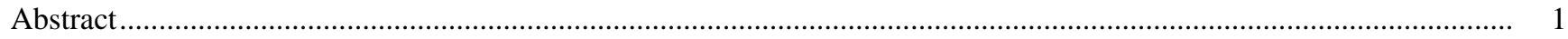

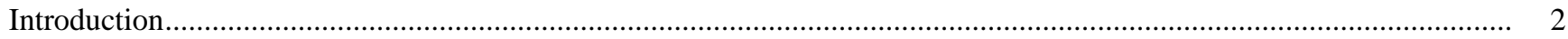

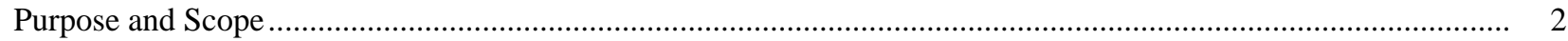

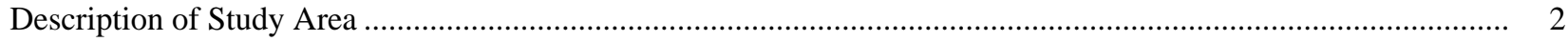

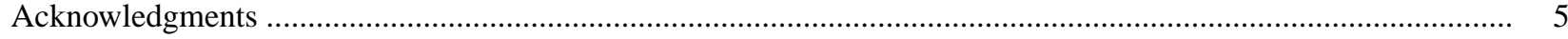

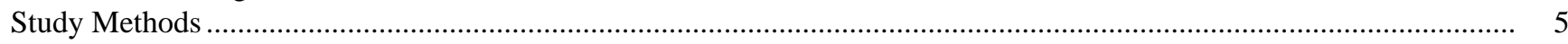

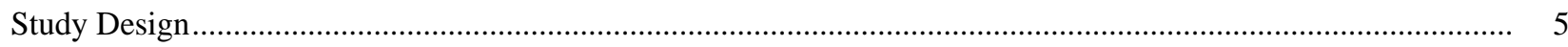

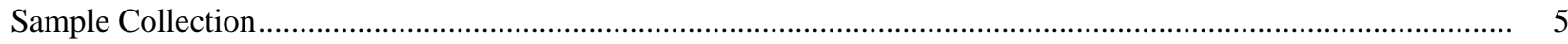

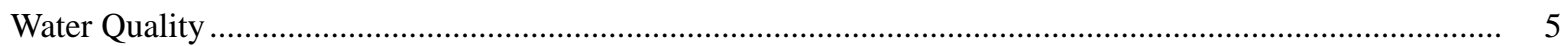

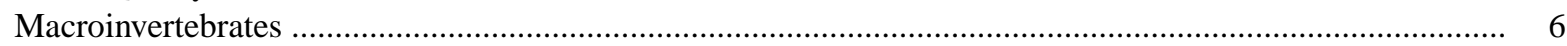

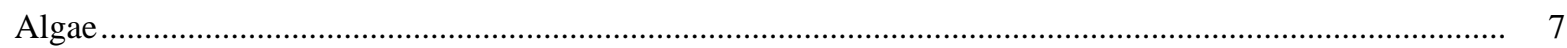

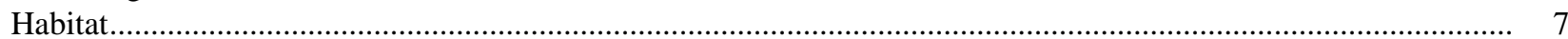

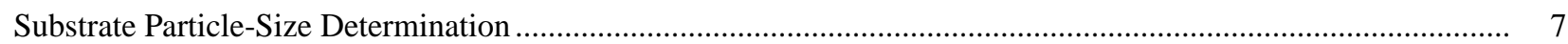

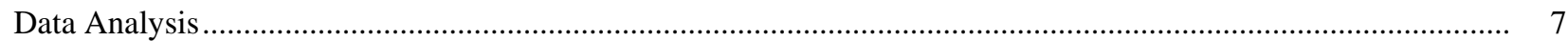

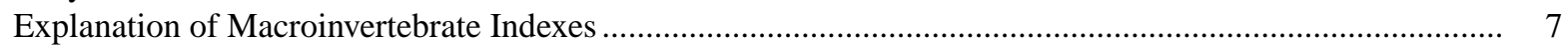

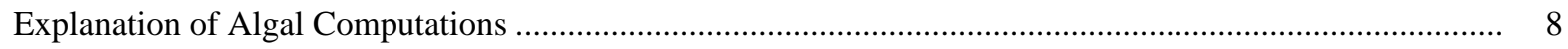

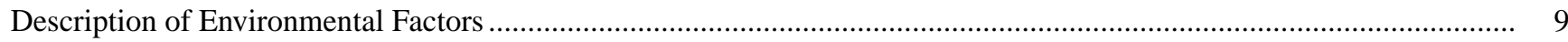

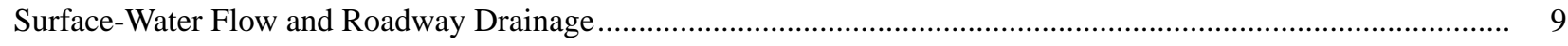

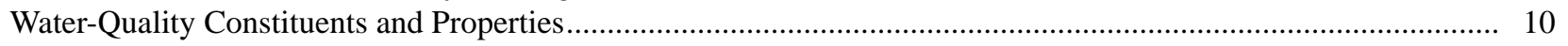

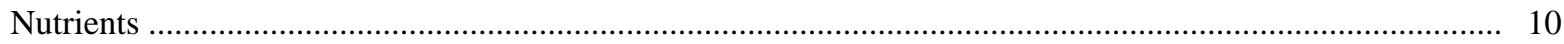

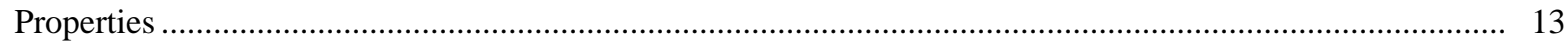

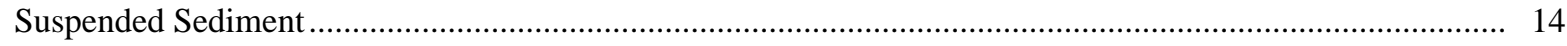

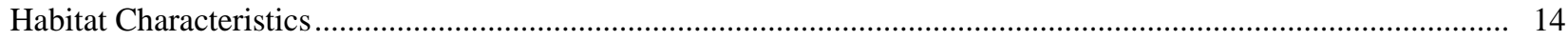

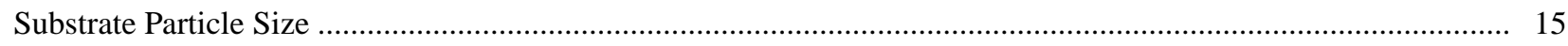

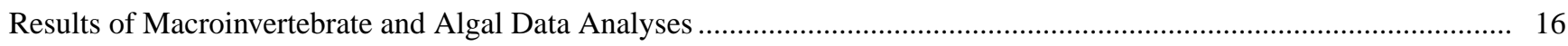

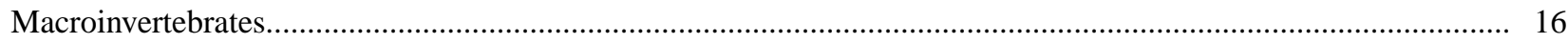

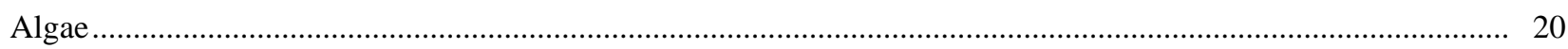

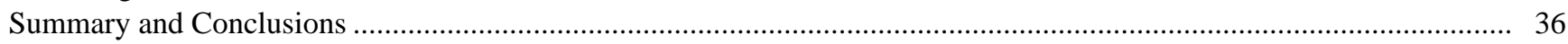

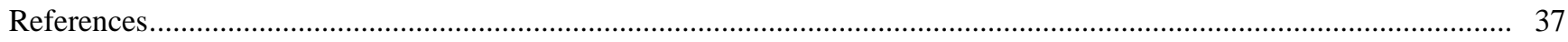

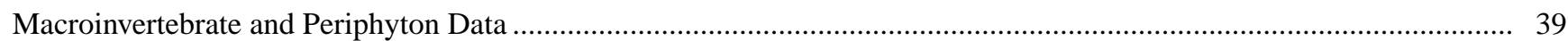

\section{FIGURES}

1. Map showing location of Guanella Pass study area and biological sample-collection sites ............................... 3

2. Graph showing annual mean discharge for Geneva Creek at Grant, Colorado, water years 1995-97 ................... 10

3. Boxplots showing concentrations or values of selected water-quality constituents and properties for

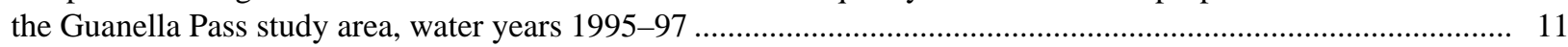

4-19. Graphs showing:

4. Habitat characterization scores for biological sampling sites, Guanella Pass study area........................... 14

5. Total number of macroinvertebrate taxa in stream reaches, Guanella Pass study area, water years 1995-97.

6. Macroinvertebrate density in stream reaches, Guanella Pass study area, water years 1995-97

7. Shannon-Weaver diversity indexes for macroinvertebrates in stream reaches, Guanella Pass study area, water years 1995-97. (1)

8. Relative abundance of macroinvertebrate functional feeding groups in stream reaches, Guanella Pass study area, water years 1995-97......

9. Relative abundance of Ephemeroptera, Plecoptera, and Trichoptera (EPT) in stream reaches of the Guanella Pass study area, water years 1995-97 ...

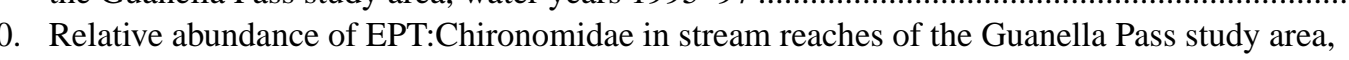
water years 1995-97.

11. Algal density in stream reaches, Guanella Pass study area, water years 1995-97....... 
12. Relative abundance of algal divisions, Guanella Pass study area, water years 1995-97 ............................. 26

13. Algal biovolume in stream reaches, Guanella Pass study area, water years 1995-97 ................................ 27

14. Relative biovolume of algal divisions, Guanella Pass study area, water years 1995-97 ............................. 28

15. Shannon-Weaver diversity index for diatoms in stream reaches, Guanella Pass study area, water years 1995-97

16. Pollution Tolerance Index (PTI) for diatoms in stream reaches of the Guanella Pass study area, water years 1995-97

17. Relative abundance of sensitive diatoms in stream reaches, Guanella Pass study area, water years 1995-97.

18. Relative abundance of motile diatoms in stream reaches, Guanella Pass study area, water years 1995-97.

19. Relative abundance of acid-tolerant diatoms in stream reaches, Guanella Pass study area, water years 1995-97....

\section{TABLES}

1. Biological sampling sites in the Guanella Pass study area..........................................................................

2. Years samples were collected at each site in the Guanella Pass study area, water years 1995-97 ..................... 4

3. Site descriptions for the biological sampling sites, Guanella Pass area, water years 1995-97 .......................... 6

4. Road-runoff linkages to biological sampling sites, Guanella Pass study area, water years 1995-97 ................... 10

5. Monthly mean water temperatures in degrees Celsius for sites with continuous water-temperature

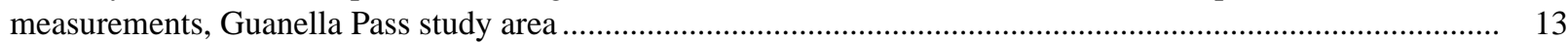

6. Habitat evaluation scores using U.S. Environmental Protection Agency Rapid Bioassessment

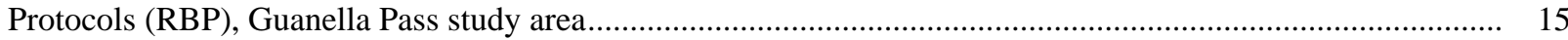

7. Slope and percent gradient for each site, Guanella Pass study area.............................................................. 15

8. Bed-material particle-size data from Wolman pebble counts at biological sampling sites, Guanella Pass study area

9. Percentage of community similarity of benthic macroinvertebrates at sites in the Guanella Pass study area, water years $1995-97$

10. Percentage of community similarity of algal abundance at sites in the Guanella Pass study area, water years 1995-97

11. Taxa and densities of macroinvertebrates collected at biological sampling sites, water year 1995 .................... 41

12. Taxa and densities of macroinvertebrates collected at biological sampling sites, water year 1996..................... 44

13. Taxa and densities of macroinvertebrates collected at biological sampling sites, water year 1997 .................... 47

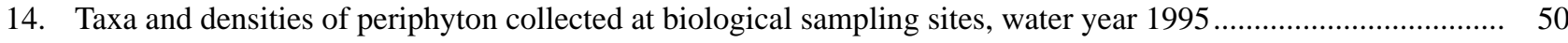

15. Taxa and densities of periphyton collected at biological sampling sites, water year 1996 ................................ 74

16. Taxa and densities of periphyton collected at biological sampling sites, water year 1997 ................................ 98 
CONVERSION FACTORS, VERTICAL DATUM, AND ABBREVIATIONS

\begin{tabular}{rll}
\hline Multiply & \multicolumn{1}{c}{ By } & To obtain \\
\hline centimeter $(\mathrm{cm})$ & 0.3937 & inch \\
square centimeter $\left(\mathrm{cm}^{2}\right)$ & 0.1550 & square inch $\left(\mathrm{in}^{2}\right)$ \\
cubic foot per second $\left(\mathrm{ft}^{3} / \mathrm{s}\right)$ & 0.02832 & cubic meter per second \\
foot $(\mathrm{ft})$ & 0.3048 & meter \\
gallon $(\mathrm{gal})$ & 3.758 & liter \\
inch & 2.54 & centimeter \\
liter $(\mathrm{L})$ & 0.2642 & gallon \\
micrometer $(\mu \mathrm{m})$ & 0.00003937 & inch \\
mile $(\mathrm{mi})$ & 1.609 & kilometer \\
milliliter $(\mathrm{mL})$ & 0.0610 & cubic inch \\
millimeter $(\mathrm{mm})$ & 0.03937 & inch \\
square foot $\left(\mathrm{ft}^{2}\right)$ & 0.0929 & square meter
\end{tabular}

Temperature in degrees Celsius $\left({ }^{\circ} \mathrm{C}\right)$ may be converted to degrees Fahrenheit $\left({ }^{\circ} \mathrm{F}\right)$ as follows:

$$
{ }^{\circ} \mathrm{F}=\left(1.8 \times{ }^{\circ} \mathrm{C}\right)+32
$$

Temperature in degrees Fahrenheit $\left({ }^{\circ} \mathrm{F}\right)$ may be converted to degrees Celsius $\left({ }^{\circ} \mathrm{C}\right)$ as follows:

$$
{ }^{\circ} \mathrm{C}=\left({ }^{\circ} \mathrm{F}-32\right) / 1.8
$$

\section{Additional Abbreviations}

cells per square centimeter (cells $\left./ \mathrm{cm}^{2}\right)$

cells per cubic centimeter $\left(\mathrm{cells} / \mathrm{cm}^{3}\right)$

cubic micrometer $\left(\mu \mathrm{m}^{3}\right)$

milligram (mg)

milligram per gram $(\mathrm{mg} / \mathrm{g})$

microgram per liter $(\mu \mathrm{g} / \mathrm{L})$

microsiemens per centimeter at 25 degrees Celsius $(\mu \mathrm{S} / \mathrm{cm})$

milligram per liter $(\mathrm{mg} / \mathrm{L})$

nephelometric turbidity unit (NTU)

organisms per square centimeter (organisms $/ \mathrm{cm}^{2}$ )

organisms per square meter (organisms $/ \mathrm{m}^{2}$ )

Sea level: In this report, "sea level" refers to the National Geodetic Vertical Datum of 1929 (NGVD of 1929)—a geodetic datum derived from a general adjustment of the first-order level nets of both the United States and Canada, formerly called Sea Level Datum of 1929. 


\title{
Evaluation of Biological Data, Guanella Pass Area, Clear Creek and Park Counties, Colorado, Water Years 1995-97
}

\author{
By Jennifer R. Cox-Lillis
}

\section{Abstract}

Macroinvertebrate and algal community samples were collected during a 3-year period at sites located near Guanella Pass, Colorado, to provide baseline characterization data. Waterquality sampling and habitat evaluations were used to aid in the interpretation of the biological data. The study was part of an environmental investigation for a proposed roadway reconstruction project on Guanella Pass. Discharge was strongly affected by snowmelt during May-July. Habitat scores were optimal (147-199), as determined by U.S. Environmental Protection Agency Rapid Bioassessment Protocol methods.

Generally, low median concentrations of nitrogen and phosphorus (less than 0.02 milligram per liter) were detected at all sites. The water temperatures ranged from 0.4 to 11.2 degrees Celsius. The average $\mathrm{pH}$ for all sites was neutral, and specific conductivities were dilute (less than 160 microsiemens per centimeter at 25 degrees Celsius). The median suspendedsediment concentration was less than 20 milligrams per liter at all sites.

During the study, 100 macroinvertebrate taxa were identified. The dominant taxonomic groups of macroinvertebrates were Diptera (true flies), Ephemeroptera (mayflies), Plecoptera (stoneflies), and Trichoptera (caddisflies). Macroinvertebrate density ranged from 6.6 to 4,300 organisms per square meter at sampled sites. Shannon-Weaver diversity values for the macroinvertebrate samples ranged from 1.6 to 4.5 .
Collector-gatherers dominated the functional feeding groups at most sites. Average abundance of Ephemeroptera, Plecoptera, and Trichoptera (EPT) was 56.7 percent; EPT:Chironomidae ratios were greater than 2:1 for every site except during water years 1996 and 1997. Chironomids were greater than EPT at four sites in water year 1996 and at one site in water year 1997. The percentage of macroinvertebrate community similarity between site pairs varied from 0 to 80 percent.

The number of algal taxa identified was 280. The dominant algal divisions, in terms of density, were Cyanophyta (blue-green algae), Chrysophyta (diatoms), Chlorophyta (green algae), Rhodophyta (red algae), and Euglenophyta (euglenoids). In general, diatom biovolumes dominated the algal assemblage, followed by blue-green algae, green algae, red algae, and euglenoids. Algal densities ranged from $3.1 \times 10^{2}$ to more than $4.7 \times 10^{6}$ cells per square centimeter, and algal biovolume ranged from $2.3 \times 10^{4}$ to $4.6 \times 10^{9}$ cells per cubic centimeter. Diversity values for diatoms ranged from 1.5 to 4.9. The pollution tolerance index (PTI) for diatoms ranged from 1.8 to 3.0. Sensitive diatoms were present at each site and ranged from 21 to 97 percent. The percentage of motile diatoms ranged from 0 to 13 percent. The presence of acid-tolerant diatoms ranged from less than 0.5 to greater than 20 percent. The percentage of community similarity between site pairs ranged from 1 to 97 percent. 
Overall, the biotic metrics that were evaluated during this study indicate that the macroinvertebrate and algal communities in the streams on Guanella Pass are not degraded by the existing road. Erosion may cause some localized effects but may not affect the overall health of the whole stream system. The degraded condition of Geneva Creek probably is due to natural effects as opposed to road effects. Although upper South Clear Creek, upstream from Naylor Creek, is located downstream from several sources of road runoff, the biological community at this site does not seem to be negatively affected.

\section{INTRODUCTION}

In 1994, the U.S. Geological Survey (USGS) began a study of the Guanella Pass area in cooperation with the Federal Highway Administration (FHWA) to characterize baseline water-quality conditions. The FHWA proposes to reconstruct and resurface the existing road over Guanella Pass between Georgetown and Grant, Colo. Water and habitat quality of streams and lakes in the area could be affected by the proposed reconstruction. This and other USGS studies are part of an environmental investigation being conducted by the FHWA.

Biomonitoring is a useful tool to evaluate the overall quality of streams. Biological communities are sensitive to short- and long-term changes in the environment. Changes in the biological community may reflect or indicate water-quality changes not detectable using one-time or infrequent sampling of water chemistry and bed sediment. Some alterations in water quality will cause an immediate change in macroinvertebrate or algal communities. Other alterations in water quality may affect the biological community over relatively long periods of time. The relative abundance of indicator species can be used to determine whether the community is stable or has been recently changed and is in the process of recolonization. Thus, biomonitoring is a useful tool for monitoring changes that might occur during road construction, and it also can help predict how biological communities might adjust during and after the construction period. This study provides information describing the existing biological communities of the Guanella Pass area that could be used for comparative purposes during and after road construction.

A previous study of the effects of road construction (Cline and others, 1982, 1983) indicates that habitat and macroinvertebrates were disrupted but recovered rapidly, possibly as a result of high stream gradients that prevented the long-term accumulation of fine sediment on the streambed.

\section{Purpose and Scope}

The purpose of this study was to describe the existing biotic community of streams in the Guanella Pass area during water years (WY) 1995-97. Macroinvertebrates and algae were collected once each water year at 14 sites (fig. 1, tables 1 and 2). Biological samples were collected at each site during low-flow conditions. Habitat evaluations were completed at each site in WY97. A water year is defined as the 12 months beginning October 1 and ending September 30 of the following year.

\section{Description of Study Area}

The study area encompasses the basins of South Clear Creek, Geneva Creek, and parts of West Chicago Creek and Deer Creek (fig. 1), which are tributary watersheds to the South Platte River. The West Chicago Creek site is adjacent to the South Clear Creek watershed and was included to provide an additional reference (natural) site. Headwaters form along the Continental Divide on the western boundary of the study area. The tributary headwaters on the eastern side of the study area are in the Mount Evans/Mount Bierstadt area.

The Guanella Pass road parallels South Clear Creek from the northern terminus at Georgetown to the top of Guanella Pass at 11,669 ft. South of the pass, the road follows Duck Creek to the confluence with Geneva Creek and then follows Geneva Creek to the southern end of the road at Grant. The road has been designated as a scenic byway and is known as Forest Highway (FH) 80. The northern 13.1-mile segment, alternatively known as Clear Creek County Road 381, is located in Clear Creek County. The southern 10.4-mile segment, also known as Park 


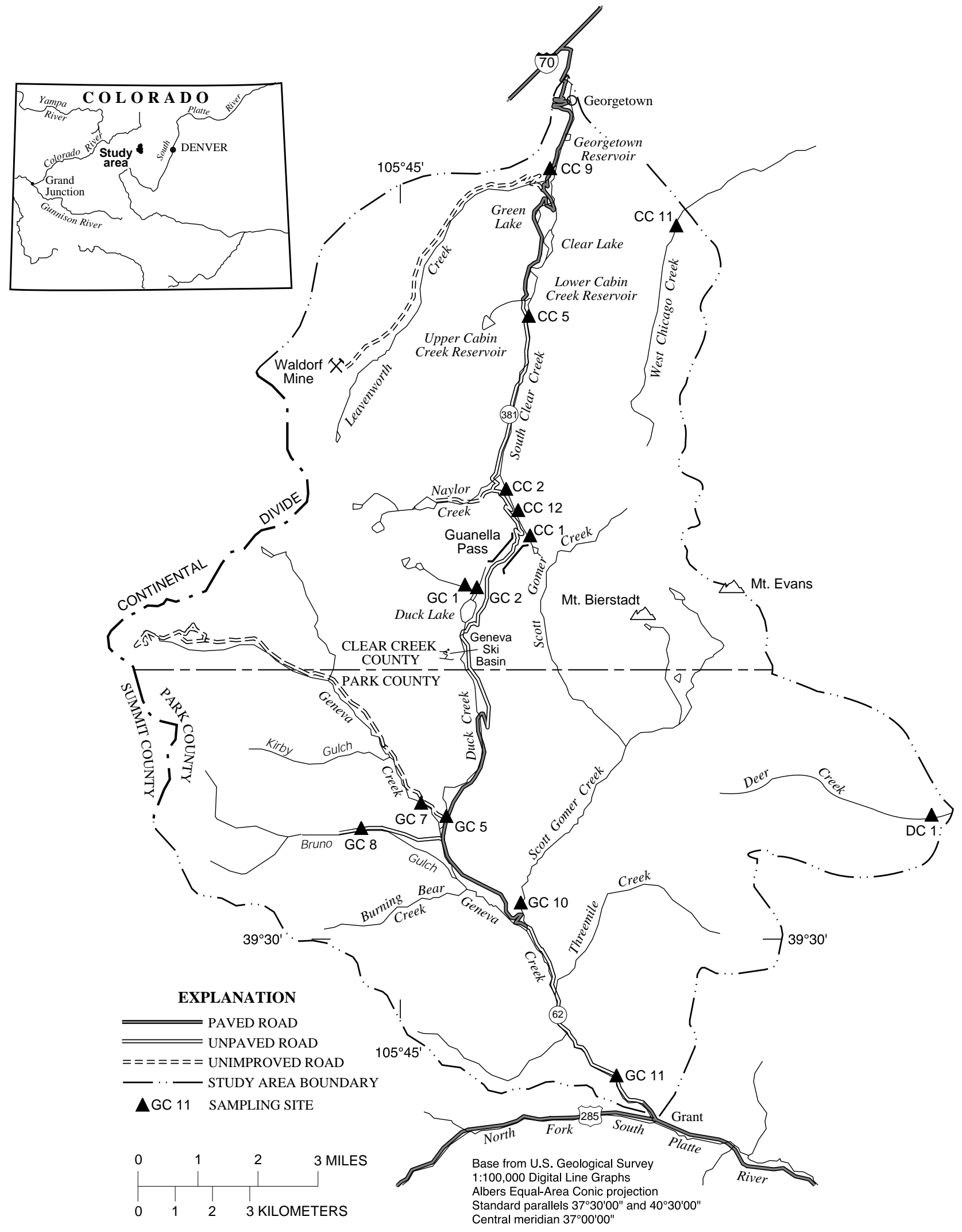

Figure 1. Location of Guanella Pass study area and biological sample-collection sites. 
Table 1. Biological sampling sites in the Guanella Pass study area

[CC, Clear Creek drainage; GC, Geneva Creek drainage; DC, Deer Creek drainage; identification number is either an eight-digit USGS downstream order number or the latitude and longitude of the site with a two-digit sequence number at the end; see figure 1 for site location]

\begin{tabular}{lll}
\hline Site & $\begin{array}{l}\text { U.S. Geological Survey } \\
\text { identification number }\end{array}$ & \multicolumn{1}{c}{ Site name } \\
\hline CC11 & 394027105393900 & West Chicago Creek near Idaho Springs, Colorado \\
CC9 & 06714800 & Leavenworth Creek at mouth near Georgetown, Colorado \\
CC5 & 06714400 & South Clear Creek above Lower Cabin Creek Reservoir near Georgetown, Colorado \\
CC2 & 363647105425317 & South Clear Creek above Naylor Creek near Georgetown, Colorado \\
CC12 & 393619105423700 & South Clear Creek above Naylor Creek at upper station near Georgetown, Colorado \\
CC1 & 393606105422118 & South Clear Creek near Guanella Pass, Colorado \\
GC1 & 393504105432312 & Duck Creek above Duck Lake West Branch near Grant, Colorado \\
GC2 & 393458105431511 & Duck Creek above Duck Lake East Branch near Grant, Colorado \\
GC5 & 06704500 & Duck Creek near Grant, Colorado \\
GC7 & 393153105440109 & Geneva Creek above Duck Creek near Grant, Colorado \\
GC8 & 393141105445808 & Bruno Gulch above Geneva Park near Grant, Colorado \\
GC10 & 393028105421706 & Scott Gomer Creek at mouth near Grant, Colorado \\
GC11 & 06705500 & Geneva Creek at Grant, Colorado \\
DC1 & 393040105340400 & Deer Creek near Bailey, Colorado \\
\hline
\end{tabular}

County Road 62, is located in Park County. The route is maintained year round by the respective counties. Salt is applied with traction material to parts of the road in Clear Creek County during winter. Magnesium chloride also has been applied to parts of the road in Clear Creek County to control dust (Jim Cannedy, Clear Creek County, oral commun., 1997). The Guanella Pass road is 23.5 miles long, of which 12.1 miles is dirt or gravel and 11.4 miles has an asphalt surface (Federal Highway Administration, 1993).

The Guanella Pass study area is sparsely populated. There are some residences at Duck Lake and along Duck, Geneva, and lower South Clear Creeks. The primary land use is recreational. Livestock grazing is a limited land use in the Geneva, Scott Gomer, and Duck Creek drainages. The disused Geneva Basin ski area is located south of Guanella Pass and Duck Lake. The Mount Evans Wilderness Area encompasses much of the eastern one-half of the study area and is closed to motor vehicles. The Vidler Tunnel diverts water from upper Peru Creek across the Continental Divide into the Leavenworth Creek Basin. An aqueduct diverts water from Leavenworth Creek on a seasonal basis for maintaining water levels in Green Lake. Some of the natural lakes have been modified for storage by the construction of small dams. Duck Lake also provides a small volume of water storage. The Public Service Company of Colorado operates two reservoirs in the South Clear Creek Basin for hydroelectric power generation.

Table 2. Years samples were collected at each site in the Guanella Pass study area, water years 1995-97

$[--$, not sampled]

\begin{tabular}{lccc}
\hline Site & \multicolumn{3}{c}{ Years sampled } \\
\cline { 2 - 4 } CC11 & 1995 & $\mathbf{1 9 9 6}$ & $\mathbf{1 9 9 7}$ \\
CC9 & $\mathrm{x}$ & $\mathrm{x}$ & $\mathrm{x}$ \\
CC5 & $\mathrm{x}$ & $\mathrm{x}$ & $\mathrm{x}$ \\
CC2 & $\mathrm{x}$ & $\mathrm{x}$ & $\mathrm{x}$ \\
CC12 & -- & $\mathrm{x}$ & $\mathrm{x}$ \\
CC1 & -- & -- & -- \\
GC1 & $\mathrm{x}$ & $\mathrm{x}$ & $\mathrm{x}$ \\
GC2 & $\mathrm{x}$ & $\mathrm{x}$ & $\mathrm{x}$ \\
GC5 & $\mathrm{x}$ & $\mathrm{x}$ & $\mathrm{x}$ \\
GC7 & $\mathrm{x}$ & $\mathrm{x}$ & $\mathrm{x}$ \\
GC8 & $\mathrm{x}$ & $\mathrm{x}$ & $\mathrm{x}$ \\
GC10 & $\mathrm{x}$ & $\mathrm{x}$ & $\mathrm{x}$ \\
GC11 & $\mathrm{x}$ & $\mathrm{x}$ & $\mathrm{x}$ \\
DC1 & -- & $\mathrm{x}$ & $\mathrm{x}$ \\
\hline
\end{tabular}


Vegetation in the study area is primarily conifer and aspen forest at lower elevations and alpine tundra above timberline, near 11,500 ft. Annual precipitation in the study area ranges between 12 to 16 inches near Georgetown and Grant and 40 to 50 inches on Mount Evans and the Continental Divide (Colorado Climate Center, 1984). Annual streamflows are characterized by peak flows in June resulting from snowmelt and by low flows during winter. Short afternoon thunderstorms occur during summer.

Precambrian granite, gneiss, and schist compose the bedrock in the study area. Intrusive rocks of Tertiary age underlie the headwaters of Geneva and Leavenworth Creeks. Glaciers deposited drift in the valleys of Duck, Geneva, and South Clear Creeks (Tweto, 1979) and created many of the natural lakes in the area. Ore deposits containing the minerals galena, sphalerite, pyrite, chalcopyrite, and tetrahedrite-tennantite were mined near the headwaters of Geneva and Leavenworth Creeks. These areas were known as the Geneva Creek District and the Argentine District, respectively (Davis and Streufert, 1990). Naturally occurring pyritic components of the intrusive rocks and mineral deposits become oxidized and produce acidic ground water and surface water in the upper basins of Geneva Creek at GC7 and Leavenworth Creek at CC9 (fig. 1) (Bassett and others, 1992).

\section{Acknowledgments}

Data collection for this report was made possible by the assistance of many people. The author thanks William and Julia Holmes for access to their property and Public Service Company of Colorado, Clear Creek and Park Counties, and the U.S. Department of Agriculture (USDA), Forest Service, for access to their properties. Appreciation also is extended to those who processed and identified the biological samples: Boris Kondratieff, entomologist and professor at Colorado State University, for identifying macroinvertebrate samples; and Frank Acker, phycologist at the Academy of Natural Sciences of Philadelphia, for identifying the algal samples. John Dick, Cristin Dyster, David Johncox, Sally Cuffin, Abby Hardie, Clay Thompson, Greg Harp, and Eric Bersagel assisted with data collection. Additional scientific expertise was provided by Cathy Tate and Stephen Porter of the USGS, as well as guidance from Mike Stevens.

\section{STUDY METHODS}

\section{Study Design}

Fourteen sites were used for the biological assessment of the study area (fig. 1, table 1). Thirteen sites were evaluated for at least 2 years (table 2). The number of sites sampled per year was as follows: WY95, 11 sites; WY96 and WY97, 13 sites. Sites were chosen on the basis of their proximity to the road and the land use in their respective basins. Seven sites were identified as sites potentially affected by the existing road, and seven sites were chosen as reference sites. The reference sites are considered representative of natural, undisturbed conditions in the area (table 3 ). One of the reference sites, GC7, was chosen to represent naturally occurring acidic conditions. Data from reference sites and non-reference sites can be compared, when appropriate, to describe any changes that might be attributed to effects of the road.

\section{Sample Collection}

\section{Water Quality}

Water-quality and biological samples were collected each year during low-flow conditions. Water-quality samples also were collected at least once during snowmelt runoff. Sites at streamflowgaging stations (CC2, CC5, GC5, GC11, and DC1) were sampled more frequently, including during snowmelt and storm-runoff periods. Samples were analyzed for major ions, nutrients, trace elements, and suspended sediment.

Specific conductance, water temperature, dissolved oxygen, and barometric pressure measurements were made at streamside (M.A. Sylvester and others, U.S. Geological Survey, unpub. data, 1990). Turbidity and $\mathrm{pH}$ were measured in samples composited in a churn splitter. Samples for inorganic analysis were collected by equal-width-increment (EWI) methods by using a $\mathrm{DH}-81$ polyethylene isokinetic sampler and were split for separate analysis with a USGS churn splitter (Ward and Harr, 1990). Samples requiring filtered water, for measuring dissolved constituents, were filtered using a peristaltic pump and a disposable $0.45-\mu \mathrm{m}$ capsule filter in an enclosed filter chamber. Samples collected for trace-element 
Table 3. Site descriptions for the biological sampling sites, Guanella Pass area, water years 1995-97

[C, camping; (fs), Forest Service Campground; (d), dispersed camping; G, grazing; W, wilderness; M, mining; NR, no road; P, residential; R, roads; (g), gravel road; (p), paved road; (s), secondary road; ft, feet; avg, average]

\begin{tabular}{|c|c|c|c|c|c|c|c|}
\hline $\begin{array}{c}\text { Site } \\
\text { number }\end{array}$ & $\begin{array}{l}\text { Reference } \\
\text { site? }\end{array}$ & $\begin{array}{l}\text { Elevation } \\
\text { (ft) }\end{array}$ & $\begin{array}{l}\text { Stream } \\
\text { width } \\
\text { (avg, ft) }\end{array}$ & $\begin{array}{c}\text { Stream } \\
\text { depth } \\
\text { (avg, ft) }\end{array}$ & Basin & $\begin{array}{l}\text { Basin } \\
\text { land use }\end{array}$ & $\begin{array}{l}\text { Natural } \\
\text { factors }\end{array}$ \\
\hline $\mathrm{CC} 11$ & Yes & 9,640 & 10 & 0.54 & $\mathrm{CC}$ & $\mathrm{NR}, \mathrm{C}(\mathrm{d})$ & Beaver dams \\
\hline CC9 & No & 9,320 & 20 & 0.82 & $\mathrm{CC}$ & $\mathrm{R}(\mathrm{p} / \mathrm{s}), \mathrm{M}$ & Lake \\
\hline CC5 & No & 10,100 & 18 & 0.49 & $\mathrm{CC}$ & $\mathrm{R}(\mathrm{g})$ & Beaver dams \\
\hline $\mathrm{CC} 2$ & No & 10,720 & 6.5 & 0.63 & $\mathrm{CC}$ & $\mathrm{R}(\mathrm{g} / \mathrm{p}), \mathrm{C}(\mathrm{fs})$ & None \\
\hline $\mathrm{CC} 12$ & No & 11,040 & 6.4 & 0.53 & $\mathrm{CC}$ & $\mathrm{R}(\mathrm{g}), \mathrm{C}(\mathrm{d})$ & None \\
\hline $\mathrm{CC} 1$ & Yes & 11,200 & 4.1 & 0.30 & $\mathrm{CC}$ & $\mathrm{W}$ & None \\
\hline GC1 & Yes & 11,240 & 4.1 & 0.55 & GC & $R(g), P$ & None \\
\hline GC2 & No & 11,240 & 5.3 & 0.30 & $\mathrm{GC}$ & NR, P & Lake \\
\hline GC5 & No & 10,000 & 13 & 0.71 & GC & $\mathrm{R}(\mathrm{g}), \mathrm{G}$ & Beaver dams \\
\hline GC7 & Yes & 9,790 & 24 & 0.72 & $\mathrm{GC}$ & $\mathrm{R}(\mathrm{s}), \mathrm{M}, \mathrm{G}, \mathrm{C}(\mathrm{fs}), \mathrm{C}(\mathrm{d})$ & Acid-sulfate weathering \\
\hline GC8 & Yes & 9,840 & 13 & 0.63 & GC & $\mathrm{NR}, \mathrm{C}(\mathrm{d})$ & None \\
\hline GC10 & Yes & 9,480 & 21 & 1.20 & GC & $C(d)$ & None \\
\hline GC11 & No & 8,760 & 46 & 0.70 & $\mathrm{GC}$ & $\mathrm{R}(\mathrm{g})$ & None \\
\hline $\mathrm{DC} 1$ & Yes & 9,750 & 6.8 & 0.50 & $\mathrm{DC}$ & $\mathrm{W}$ & None \\
\hline
\end{tabular}

analysis were preserved with ultrapure nitric acid (to $\mathrm{pH}$ less than 2) or nitric acid and potassium dichromate (for mercury samples). Nutrient samples were preserved by chilling to less than $4^{\circ} \mathrm{C}$. Suspendedsediment samples were collected using a DH-48 glass isokinetic sampler and the EWI method (Edwards and Glysson, 1988). Water-quality samples were analyzed by the USGS National Water Quality Laboratory in Arvada, Colo., using standard analytical techniques (Wershaw and others, 1987; Fishman and Friedman, 1989; Fishman, 1993; and Fishman and others, 1994).

\section{Macroinvertebrates}

Eleven sites were sampled for benthic macroinvertebrates in WY95, and 13 sites were sampled in WY's 1996-97 (table 2). Macroinvertebrate communities were sampled during late summer at low-flow conditions using a Hess sampler with a 500- $\mu$ m nylonmesh net. A small nylon brush was used to dislodge macroinvertebrates from small boulders, cobbles, and large gravel (hereinafter referred to as "substrate") that fit by at least 50 percent within the cylindrical Hess sampler. The substrate sample was inspected for remaining invertebrates and then returned to the stream, away from other potential sampling areas. Reinforcing bar was used to stir the remaining substrate to dislodge any macroinvertebrates that might be living in the streambed material. The streambed material was stirred to a depth of approximately $10 \mathrm{~cm}$ for each sample to ensure sample comparability. Organisms clinging to the inside of the mesh were removed with forceps or native stream water. Five Hess samples were collected in riffle areas, the richest target habitat (RTH), which is the stream habitat where macroinvertebrate populations are richest (Cuffney and others, 1993). Richness is a term used to define the number of taxa identified at each site. Depositional samples were not collected because there were very few depositional areas due to the nature of high-gradient streams. Samples were collected from downstream to upstream to prevent disturbing the habitat. The Hess sampler covered $1 \mathrm{ft}^{2}$, giving a total sample area per reach of $5 \mathrm{ft}^{2}$. Due to high stream gradient and coarse substrate material, the sampling sites were chosen based on accessibility, ability to use the Hess sampler properly, and an estimate of locations that would be the richest in macroinvertebrate populations. The Hess samples were put into a wide-mouth plastic jar and preserved with 3-5 percent buffered formalin solution.

The macroinvertebrate samples were processed, identified, and counted by Boris Kondratieff (Colorado State University, written commun., 1997) in Fort Collins, Colo. Samples were placed in a $0.25-\mu \mathrm{m}$ 
(no. 60) sieve and rinsed with tap water to remove the formalin. The organisms were sorted under a binocular dissecting microscope to separate the invertebrates from debris and then were placed in a vial containing 70-80 percent ethanol. The organisms were identified to the lowest practical taxonomic level and counted. Several references were used in the identification of the macroinvertebrates: Merritt and Cummins (1996) as a general reference; Edmunds and others (1976) for Ephemeroptera (mayflies); Stewart and Stark (1988) for Plecoptera (stoneflies); Wiggins (1996) for Trichoptera (caddisflies); and Pennak (1989) and Thorp and Covich (1991) for macroinvertebrates other than insects.

\section{Algae}

Algal communities were sampled using a SG-92 (Porter and others, 1993). The SG-92 is constructed by gluing an O-ring to the flange end of the barrel of a syringe. Quantitative samples were collected by using a brush to remove attached algae contained within the circular base of the SG-92 sampler. The surface area sampled was $3.66 \mathrm{~cm}^{2}$. The algae-water mixture was then pipetted into a widemouth jar. Within each sampled stream reach, five large rocks were chosen at each of five cross sections, and the SG-92 was used to sample five areas of each rock. A total area of $458 \mathrm{~cm}^{2}$ was composited for each stream reach.

Algal samples were processed by the Academy of Natural Sciences of Philadelphia (ANSP) in accordance with specifications given by the USGS National Water-Quality Assessment (NAWQA) Program (Stephen Porter, U.S. Geological Survey, written commun., 1998). Algae were identified to lowest practical taxon, generally to species and variety for diatoms and to genus or species for other algal taxa. A subsample of the algal sample was withdrawn and cleaned chemically to facilitate identification of diatom species. A minimum of 300 algal cells or counting units were identified, and algal species lists were prepared using the results. Cell abundance was calculated in accordance with the original sample volume measured by the ANSP and the rock surface area from which algae were collected. Biovolume was calculated by averaging three-dimensional measurements of several cells from each taxon. The total biovolume was calculated by multiplying the average biovolume per cell by the abundance.

\section{Habitat}

Stream gradients were calculated for each site from topographic contours on 7.5-minute USGS quadrangle maps. Stream habitat was described at each biological sampling station using Rapid Bioassessment Protocols (RBP) from the U.S. Environmental Protection Agency (USEPA) handbook (Plafkin and others, 1989). The USEPA protocols are based on three levels of assessment. The primary level characterizes the embeddedness of the streambed, which affects community structure because some insects require protected areas while others thrive in heavily sedimented areas. A secondary-level assessment investigates the channel morphology; this parameter also influences community structure because different organisms thrive in habitat types specific to different geomorphic channel units. Tertiary-level assessments of habitat includes the characterization of riparian and bank structure (Plafkin and others, 1989). Riparian habitat influences the composition of instream communities in many ways: (1) It provides a canopy that could limit light, (2) it prevents the settling of dust in certain areas, (3) it can act as a filter when water passes through it, and (4) it stabilizes streambanks.

\section{Substrate Particle-Size Determination}

A Wolman pebble count was conducted at each site to characterize the substrate particle-size distribution. One hundred rocks were chosen by investigators walking in a zigzag pattern, from bank to bank, then the three dimensions of each rock were measured and averaged (Wolman, 1954). If a selected rock measured less than $4 \mathrm{~mm}$ in diameter, a $40-\mathrm{cm}^{3}$ sample of substrate material was collected and then composited, wet sieved, and integrated into the particle-size distribution.

\section{Data Analysis}

\section{Explanation of Macroinvertebrate Indexes}

Macroinvertebrates were collected at all of the biological monitoring sites in the RTH. Macroinvertebrates are especially useful in defining the effects of measured water quality because they are sensitive to relatively long-term changes in water quality. Community structure can be used to evaluate 
instream conditions and land-use effects. As water quality degrades, communities become less diverse and structure can shift, favoring those species that are more tolerant of degraded conditions. The documented responsiveness of invertebrates to changing environmental conditions makes them a suitable choice for biomonitoring (Merritt and Cummins, 1996). Macroinvertebrate communities were evaluated using density, taxa richness, diversity, functional feeding measures, and community composition (Klemm and others, 1990).

Density, Taxa Richness, and Diversity. Macroinvertebrate density (the number of organisms collected at each site) was reported as number of individuals per square meter. This number, alone, is not an accurate measure of stream health and should be analyzed in conjunction with taxa richness. The Shannon-Weaver diversity index, which is a function of density and taxa richness, was used to measure diversity,

$$
\bar{d}=\frac{C}{N}\left(N \log 10 N-\sum n_{i} \log n_{i}\right)
$$

where

$$
\begin{aligned}
& \bar{d} \quad \text { is diversity, } \\
& C \quad \text { is } 3.322 \text { (converts base } 10 \text { log to base 2), } \\
& N \quad \text { is the total number of individuals, and } \\
& n_{i} \quad \text { is the total number of individuals of the } \\
& \quad i \text { th species. }
\end{aligned}
$$

Diversity is commonly used to help further define density and taxa richness values.

Functional Feeding Group Measures. The presence of different macroinvertebrate functional feeding groups reflects available resources (Merritt and Cummins, 1996). Individual taxa were assigned to a functional feeding group (predators, collectorfilterers, shredders, scrapers, collector-gatherers, and generalists) similar to classifications in Merritt and Cummins (1996).

EPT. The number of taxa and relative abundance of Ephemeroptera, Plecoptera, and Trichoptera (EPT) indicate whether macroinvertebrate communities are affected by pollution. This is based on the concept that most of the taxa in these orders are sensitive to pollution (Rosenberg and Resh, 1993). EPT values are expected to decrease as water-quality conditions degrade (Plafkin and others, 1989).
EPT:Chironomidae. The ratio of EPT to Chironomidae should be equitable, if not favoring the EPT species, in natural stream conditions (Klemm and others, 1990). However, the ratio commonly is skewed in favor of the Chironomidae family as water quality is degraded because many chironomids are more pollution tolerant than the pollution-sensitive EPT taxa (Rosenberg and Resh, 1993).

Community Similarity. Similarity measures are used to compare macroinvertebrate communities to each other. Community similarity measures can be used to determine whether shifts occur in the community assemblages along a stream gradient-for example, upstream and downstream from a stressed area-and for comparisons between control and reference sites (Klemm and others, 1990). Community similarities were calculated according to Brower and Zar (1984).

\section{Explanation of Algal Computations}

Algal communities are present in nearly every aquatic system and can be used to evaluate water quality over relatively short periods of time. Algae react quickly to changes in the aquatic habitat because they have short life cycles and because their populations are removed and recolonized quickly in response to changing water quality (Metzmeier, 1994). Because different species thrive under different conditions, algae are useful in describing water quality. Certain types of algal cells can withstand harsh conditions, whereas other types have low tolerance for any pollution (Bahls, 1992). Several metrics were used in the bioassessment because they are more likely to accurately detect water-quality degradation in that they analyze more than one attribute of a community (Metzmeier, 1994). Algal communities were evaluated using abundance, biovolume, and several other RBP metrics.

Abundance and Biovolume. Abundance of algal cells was reported as number of cells per square centimeter (cells $/ \mathrm{cm}^{2}$ ). The biovolume for each taxon was calculated to determine the number of cells per cubic centimeter (cells $/ \mathrm{cm}^{3}$ ); this measurement is used to determine species dominance.

Shannon-Weaver Diversity Index for Diatoms. This metric was used because of its historical application and because it is sensitive to changes in water quality (Plafkin and others, 1989). The index number is affected by the number of species in a sample and the distribution of individuals among those species (Klemm 
and others, 1990). Because species richness varies under certain conditions, the calculated ShannonWeaver diversity values are sometimes misleading (Plafkin and others, 1989). According to Metzmeier (1994), Shannon-Weaver diversity values less than or equal to 2.36 represent degraded water quality, whereas diversity values greater than 4.17 represent pristine water quality.

Pollution Tolerance Index (PTI). The PTI is a metric in which values are assigned to each diatom taxon relative to its pollution tolerance (Bahls, 1992). PTI values range from 1 to 3 (1 being the most tolerant and 3 being most intolerant to pollution), as described in Lange-Bertalot (1979). The abundance of each species was multiplied by the assigned value; the numbers were then summed and divided by the total number of individuals.

Percentage of Sensitive Diatoms. The metric of percentage of sensitive diatoms is calculated as the sum of the relative abundance of all intolerant diatom species, as modified from Metzmeier (1994), from the PTI list. This index is helpful in defining water quality in small-order, high mountain streams, which are naturally low in productivity and are sometimes underestimated in terms of water quality (Plafkin and others, 1989).

Percentage of Motile Diatoms. Percentage of motile diatoms is a siltation index for algae, as suggested in Bahls (1992). The metric indicates the relative abundance of motile diatoms (Navicula + Nitzschia + Surirella), which can indicate the degree of sedimentation on the stream bottom. These genera are used because they are adapted to holding their position on unstable substrates and have the ability to avoid siltation and move to the substrate surface (Bahls, 1992).

Percentage of Acid-Tolerant Diatoms. Classifications for acid tolerance from Van Dam and others (1994) were used to rank each species on a scale from 1 to 3 ( 1 being the most tolerant and 3 being the most sensitive). The percentages of the most tolerant species were reported.

Percentage of Community Similarity. Community similarity within diatom assemblages was calculated for each site pair to show similarities between sites and gives weight to the more dominant taxa (Plafkin and others, 1989). The relative abundance for diatoms was used to calculate this value.

\section{DESCRIPTION OF ENVIRONMENTAL FACTORS}

Many sections of stream reaches in the study area run parallel to the Guanella Pass road. Several factors may affect the biological communities. Surface-water flow varies seasonally and could have a scouring effect on the biological communities during high-flow periods. Aquatic habitats could be affected by the existing road in the form of runoff from bed material and sedimentation. Changes in water quality also can affect biological communities. These factors-surfacewater flow, roadway drainage, and water quality - were chosen because they have a direct connection to the streams and are most likely to be affected during road construction.

\section{Surface-Water Flow and Roadway Drainage}

Macroinvertebrate and algal species have a preferred set of environmental conditions in which they thrive. Variations in surface-water flow can affect community structure from year to year. Mean annual discharge at Geneva Creek at Grant (GC11) was strongly influenced by melting snow from May through July (fig. 2). Relatively low, stable flows are characteristic of the late summer (August-September) and winter (October-April) periods. Biotic populations shifted in relation to the changing environmental factors. The occurrence of peak flow and normal base flows varied temporally each year. Relatively high flows in WY95 may have caused more disruption of habitat relative to the lower flows during WY96 and WY97.

The existing road is located near some stream sites on Guanella Pass; therefore, habitat, streamwater quality, and substrate have the potential to be affected by the road through runoff and sedimentation. Obvious streambank erosion in the study area is the result of fluvial entrainment of bank material by high discharges (Waters, 1995). There are prominent areas where ditches extend from the road to the stream where debris flows have formed. Basin drainage area, total ditch length along the road, and total stream linked-ditch length (a sum of the lengths of the road segments contributing runoff to the stream) were measured and used to calculate the percentage of stream-linked ditch and road drainage yield (table 4). This information was included in the study because it may show the relative contribution of road runoff to different stream reaches. 


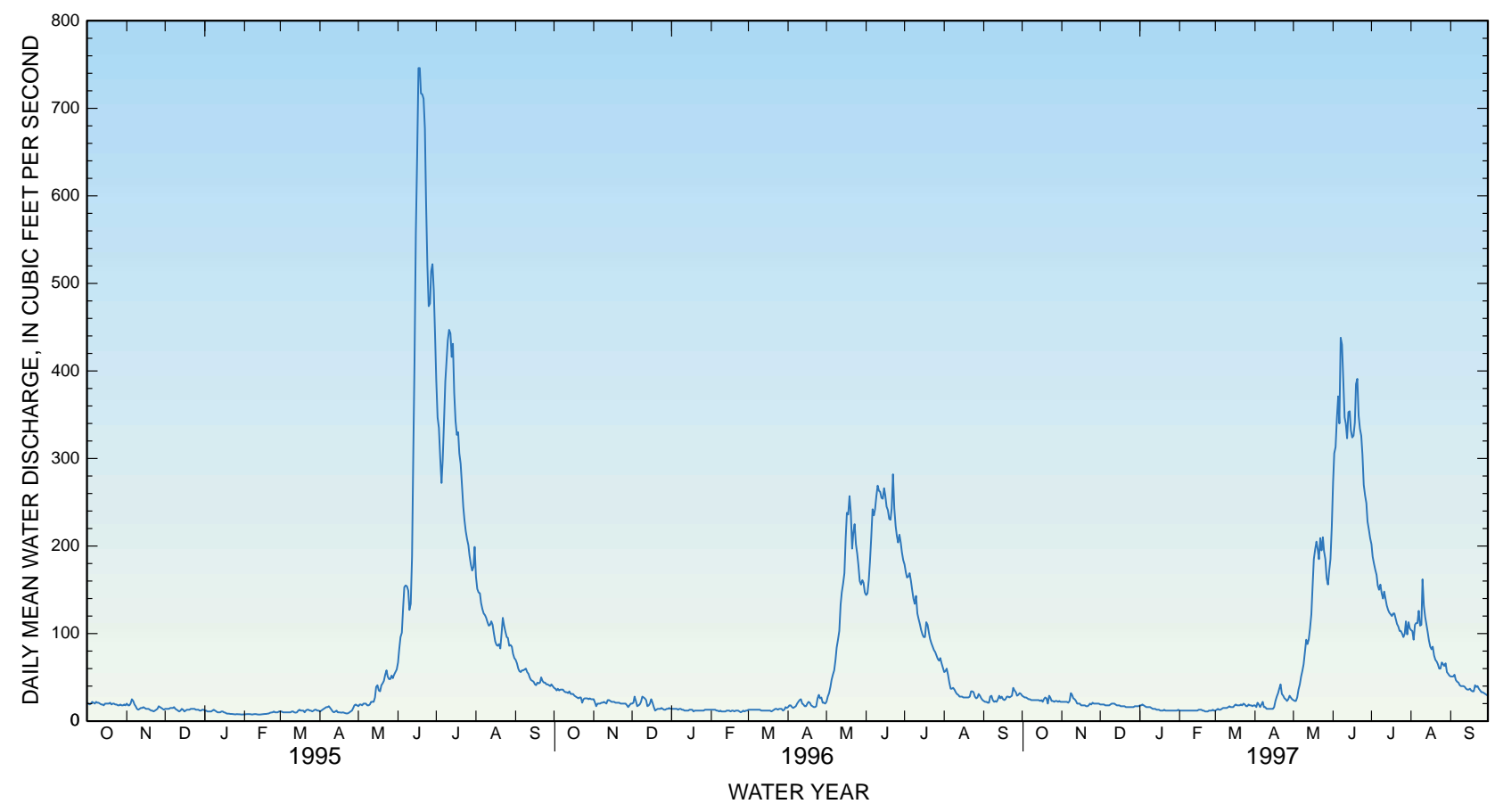

Figure 2. Annual mean discharge for Geneva Creek at Grant, Colorado, water years 1995-97.

Table 4. Road-runoff linkages to biological sampling sites, Guanella Pass study area, water years 1995-97 [ft, feet; $\mathrm{mi}^{2}$, square miles]

\begin{tabular}{lcccccr}
\hline Site & $\begin{array}{c}\text { Altitude } \\
\text { (in feet above } \\
\text { sea level) }\end{array}$ & $\begin{array}{c}\text { Basin } \\
\text { drainage area } \\
\left(\mathbf{m i}^{2}\right)\end{array}$ & $\begin{array}{c}\text { Total } \\
\text { ditch length } \\
(\mathbf{f t})\end{array}$ & $\begin{array}{c}\text { Total } \\
\text { stream-linked } \\
\text { ditch length } \\
(\mathbf{f t})\end{array}$ & $\begin{array}{c}\text { Percentage of } \\
\text { stream-linked } \\
\text { ditch }\end{array}$ & $\begin{array}{c}\text { Road } \\
\text { drainage yield } \\
\left(\mathbf{f t} / \mathbf{m i}^{2}\right)\end{array}$ \\
\hline $\mathrm{CC} 12$ & 11,030 & 1.45 & 6,009 & 4,533 & 75 & 3,126 \\
$\mathrm{CC} 2$ & 10,710 & 2.19 & 7,459 & 5,983 & 80 & 2,732 \\
$\mathrm{CC} 5$ & 10,100 & 11.8 & 18,525 & 13,992 & 76 & 1,186 \\
$\mathrm{CC}{ }^{1}$ & 9,280 & 12. & 1,404 & 1,129 & 80 & 94 \\
$\mathrm{GC} 2$ & 11,160 & 0.79 & 4,631 & 1,416 & 31 & 1,792 \\
$\mathrm{GC5}$ & 9,750 & 7.78 & 22,782 & 10,112 & 44 & 1,300 \\
$\mathrm{GC} 11^{1}$ & 8,760 & 74.6 & 52,859 & 26,647 & 50 & 357 \\
\hline
\end{tabular}

${ }^{1}$ Computations include only Guanella Pass road; extensive secondary roads in the basin are not a factor in computations.

\section{Water-Quality Constituents and Properties}

\section{Nutrients}

Concentrations of nutrients affect primary productivity in streams of the Guanella Pass study area. Median concentrations of nitrite plus nitrate nitrogen (fig. 3) and ammonia nitrogen (fig. 3) were relatively low (less than or equal to $0.002 \mathrm{mg} / \mathrm{L}$ ) during WY95-97. Median concentrations of orthophosphorus (fig. 3) and total phosphorus (fig. 3) were less than $0.02 \mathrm{mg} / \mathrm{L}$ during the study. The low phosphorus concentrations at most sites indicate that phosphorus may be a limiting factor in primary productivity. However, because nitrogen and phosphorus are present only at low concentrations, the lack of both nutrients probably limits algal growth. 


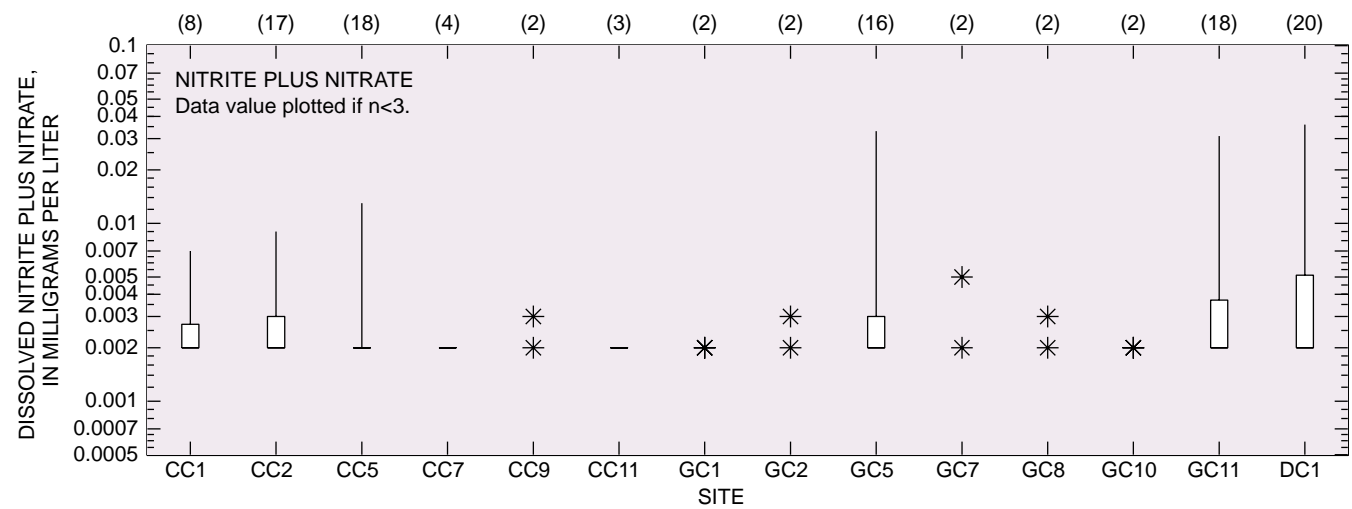

EXPLANATION

(3) Number of samples

Maximum value

75th percentile

Median

25th percentile

Minimum value

Detection limit

* Data value

Data value plotted if $n<3$.
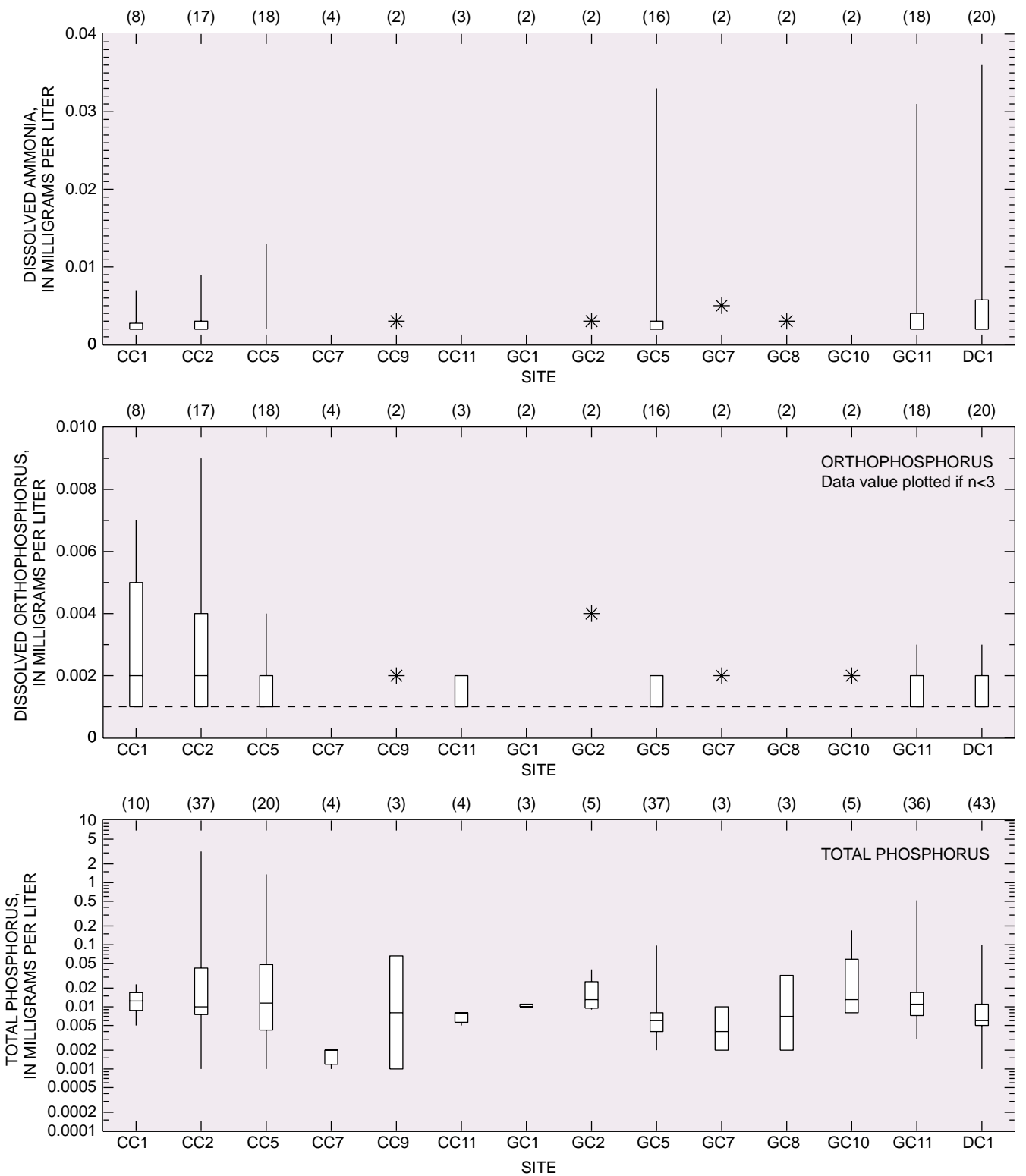

Figure 3. Concentrations or values of selected water-quality constituents and properties for the Guanella Pass study area, water years $1995-97$. 

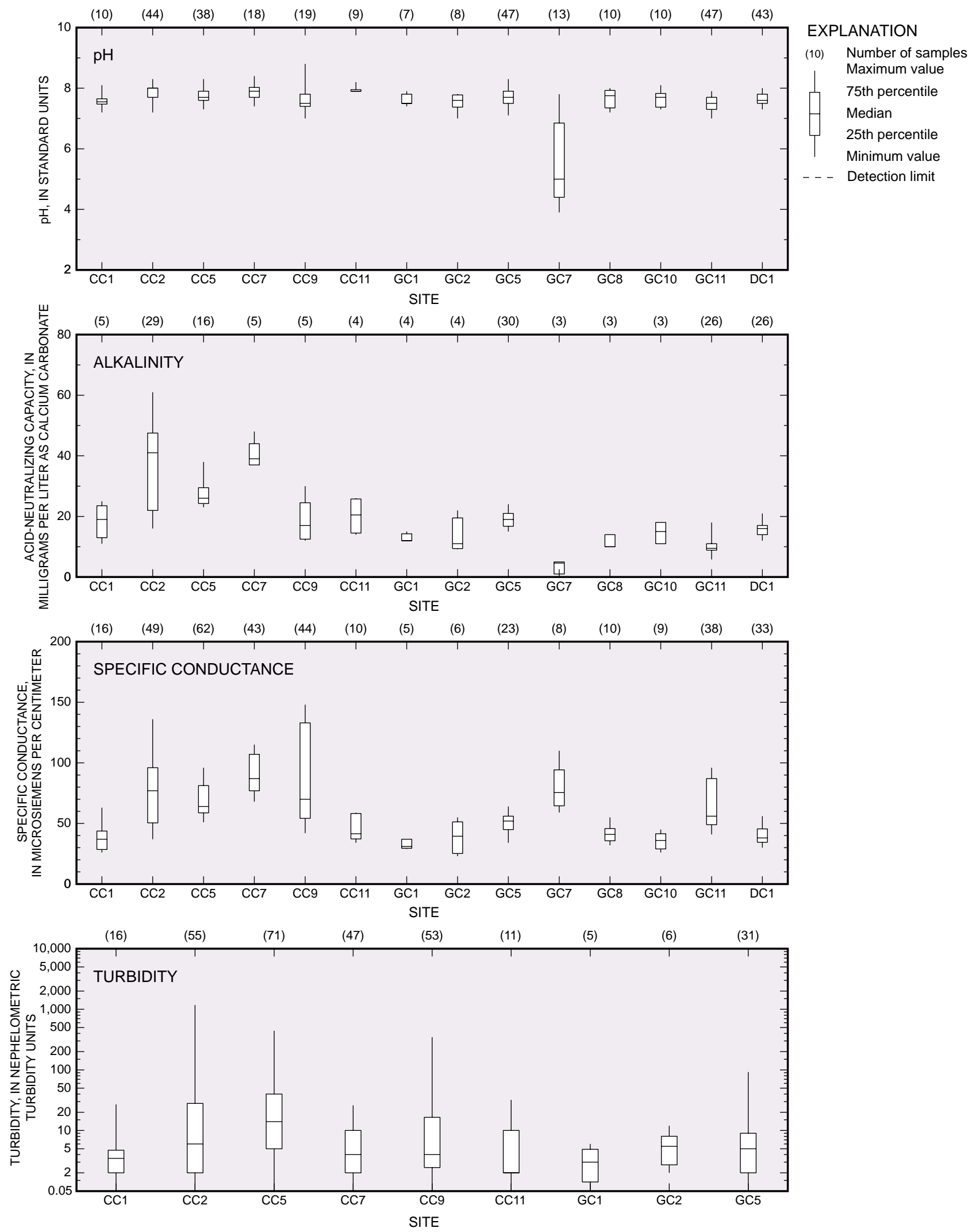

Figure 3. Concentrations or values of selected water-quality constituents and properties for the Guanella Pass study area, water years 1995-97-Continued. 


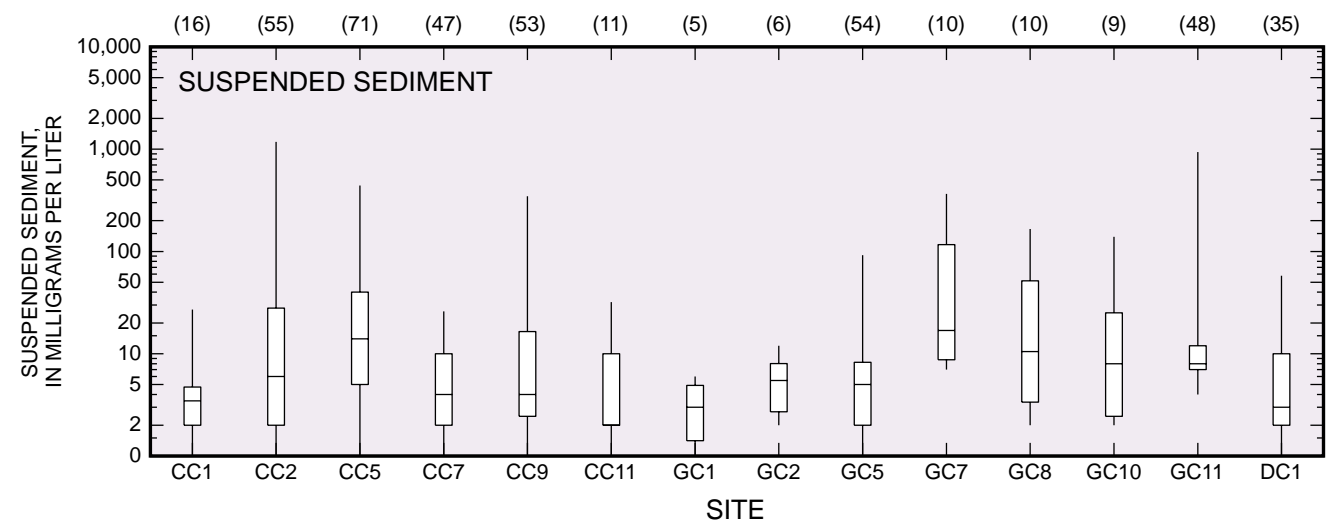

Figure 3. Concentrations or values of selected water-quality constituents and properties for the Guanella Pass study area, water years 1995-97-Continued.

Table 5. Monthly mean water temperatures in degrees Celsius for sites with continuous water-temperature measurements, Guanella Pass study area

[ft, feet; --, no data; WY, water year]

\begin{tabular}{|c|c|c|c|c|c|c|c|c|c|}
\hline \multirow{2}{*}{ Site } & \multirow{2}{*}{$\begin{array}{l}\text { Elevation } \\
\text { (ft) }\end{array}$} & \multicolumn{4}{|c|}{ WY1996 } & \multicolumn{4}{|c|}{ WY1997 } \\
\hline & & May & June & July & August & May & June & July & August \\
\hline $\mathrm{CC} 1$ & 11,200 & -- & -- & -- & -- & -- & -- & -- & - \\
\hline $\mathrm{GC} 2$ & 11,160 & 0.5 & 5.7 & -- & 7.4 & 0.4 & 5.4 & 7.7 & 7.5 \\
\hline $\mathrm{GC} 1$ & 11,160 & 1.7 & 5.3 & 10.1 & -- & -- & -- & -- & -- \\
\hline $\mathrm{CC} 2$ & 10,710 & -- & 5.7 & 8.4 & 7.1 & 0.9 & 5.8 & 7.6 & 7.8 \\
\hline CC5 & 10,100 & 3.1 & 6.1 & 8.3 & 8.4 & 3.2 & 5.9 & 7.4 & 8.2 \\
\hline GC5 & 9,750 & 5.4 & 6.8 & 9.7 & 8.7 & 4.7 & 6.4 & 9 & 8.7 \\
\hline CC11 & 9,730 & 3.6 & 7.1 & 9.6 & 8.9 & 3 & 6.3 & 8.2 & 8.1 \\
\hline GC10 & 9,380 & 2.8 & 8.1 & 11.2 & 9.4 & 3 & 7 & 10.2 & 9 \\
\hline CC9 & 9,280 & 2.3 & 4.7 & 7.9 & 8.2 & 2.1 & 4.6 & 7.1 & 8 \\
\hline DC1 & 9,280 & -- & 5 & 7 & 6.8 & 2.4 & 4.6 & 6.2 & 6.8 \\
\hline GC11 & 8,760 & 5.3 & 7.7 & 10.9 & 10.4 & 4.8 & 7.2 & 9.8 & 9.7 \\
\hline
\end{tabular}

\section{Properties}

The highest specific-conductance values generally were recorded during the winter months and during storm events. Low specific conductance generally was measured during snowmelt conditions. Within sites, specific conductance was relatively constant over the 3-year period (fig. 3). Turbidity ranged from 0 to 1,000 nephelometric turbidity units (NTU) (American Public Health Association and others, 1992) in stream samples (fig. 3). The highest turbidities (500-1,000 NTU) were recorded at CC2 and CC5, which are adjacent to the road. The highest turbidities usually occurred during snowmelt conditions or during a storm event. The median $\mathrm{pH}$ values were neutral at all sites (fig. 3) except GC7, where median $\mathrm{pH}$ was 5.0, a result of natural acid-sulfate weathering. Sampling site GC7 also had the lowest alkalinity (fig. 3).

During WY95, stream-water temperatures were recorded during sample collection. In WY96 and WY97, water temperatures were recorded continuously. The mean water temperature over the 2-year period was $6.7^{\circ} \mathrm{C}$. A maximum of $11.2^{\circ} \mathrm{C}$ and a minimum of $0.4^{\circ} \mathrm{C}^{1}$ were recorded from May to August (table 5) in 1996 and 1997. The coolest water temperatures were recorded at the highest elevation sites (GC2 and CC1) during winter months, and the warmest water temperatures were recorded at the lower elevation sites (GC10 and GC11). Stream

\footnotetext{
${ }^{1}$ The actual minimum temperature was $0^{\circ}$ during the winter months.
} 
temperatures at the lower elevation sites ranged from 2.1 to $11.2^{\circ} \mathrm{C}$. This variation in temperature probably is due to the effects of upstream water bodies such as lakes or beaver ponds, which can artificially increase or decrease water temperature.

\section{Suspended Sediment}

Median suspended-sediment concentrations, from equal-width-increment (EWI) stream samples, were less than $20 \mathrm{mg} / \mathrm{L}$ for all sites (fig. 3). Site CC2 had the greatest range of suspended-sediment concentrations ( 0 to greater than $1,000 \mathrm{mg} / \mathrm{L})$. Median suspended-sediment concentrations were highest at GC7. The short period of record and the large yearly fluctuations in suspended-sediment concentrations make it difficult to identify differences among sites.

\section{Habitat Characteristics}

Habitat conditions were characterized in this study because of their influence on biotic communities. The USEPA Rapid Bioassessment Protocol (Plafkin and others, 1989) was used to evaluate the habitat at sites where biological samples were collected. Using this technique, the sites were ranked on the basis of three main criteria: riparian zone quality, bank characteristics, and instream habitat. Streambank ranks are based on relative comparisons among sites. Theoretically, the reference sites, with which study sites are compared, represent optimal conditions.

Habitat characteristics were matched with descriptions and given a score for each category. The riparian habitat (score: 0-20) was scored by evaluating vegetation types and width of riparian zones at five cross sections in each reach. Bank stability, height, shape, and vegetation/substrate types (score: 0-40) were used to score bank characteristics. The instream habitat (score: 0-140) was scored by evaluating suitable habitat (substrate type, embeddedness, riffle quality, and so forth) for macroinvertebrate and algal communities. Habitat scores at study sites of the Guanella Pass area all ranked within the optimal range (147-199), according to USEPA RBP (Plafkin and others, 1989), at all biomonitoring sites (fig. 4 and table 6), which indicates that habitat quality at the sampling sites was generally favorable for sustaining biotic communities.

Gradients for each site (table 7) ranged from 2 percent (CC5) to 32 percent (GC1). Sites with lower gradients generally were characterized by finer substrate and a greater abundance of pollution-tolerant macroinvertebrate and algal species and, at some sites, lower macroinvtertebrate densities overall (CC5 and CC12). The lower gradient areas also were more likely to have better established riparian areas in terms of vegetation and bank stability.

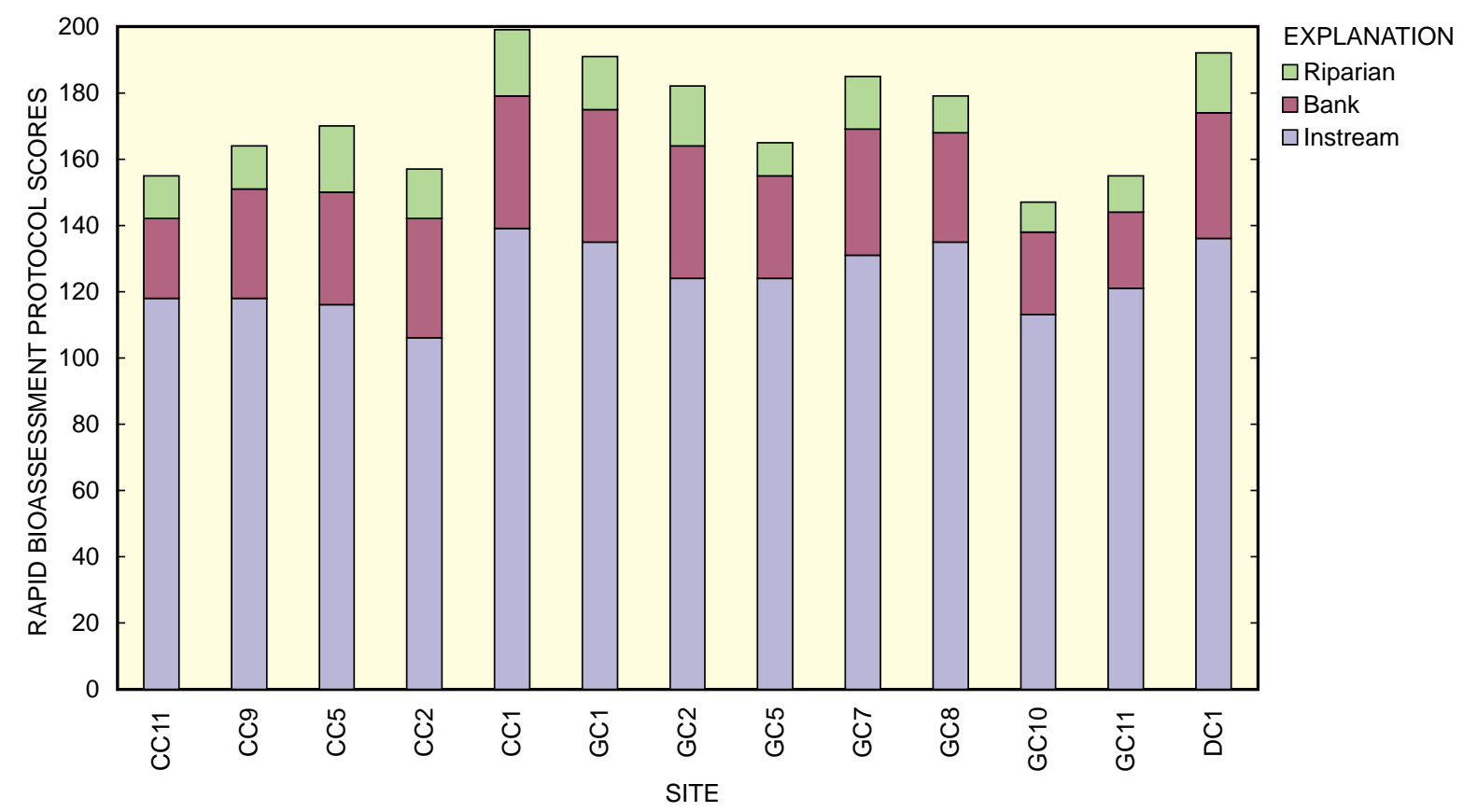

Figure 4. Habitat characterization scores for biological sampling sites, Guanella Pass study area. 
Table 6. Habitat evaluation scores using U.S. Environmental Protection Agency Rapid Bioassessment Protocols (RBP), Guanella Pass study area

[Note: Site CC12 was not evaluated using RBP]

\begin{tabular}{|c|c|c|c|c|c|c|c|c|c|c|c|c|c|}
\hline \multirow{2}{*}{ Habitat parameter } & \multicolumn{13}{|c|}{ Site } \\
\hline & CC11 & CC9 & CC5 & CC2 & CC1 & GC1 & GC2 & GC5 & GC7 & GC8 & GC10 & GC11 & DC1 \\
\hline Epifaunal substrate/available cover & 20 & 18 & 19 & 19 & 20 & 20 & 18 & 20 & 15 & 19 & 18 & 18 & 18 \\
\hline Riffle quality & 13 & 19 & 19 & 14 & 20 & 20 & 20 & 15 & 20 & 19 & 10 & 14 & 19 \\
\hline Embeddedness & 18 & 19 & 19 & 10 & 20 & 20 & 17 & 17 & 19 & 20 & 20 & 20 & 20 \\
\hline Channel alteration & 15 & 18 & 10 & 20 & 20 & 20 & 20 & 20 & 20 & 20 & 15 & 19 & 19 \\
\hline Sediment deposition & 19 & 19 & 17 & 10 & 20 & 20 & 14 & 15 & 19 & 19 & 15 & 15 & 20 \\
\hline Frequency of riffles/velocity-depth combinations & 19 & 10 & 15 & 18 & 19 & 15 & 15 & 18 & 19 & 19 & 16 & 19 & 20 \\
\hline Channel flow status & 14 & 15 & 17 & 15 & 20 & 20 & 20 & 19 & 19 & 19 & 19 & 16 & 20 \\
\hline Bank vegetative protection, left bank & 9 & 10 & 9 & 9 & 10 & 10 & 10 & 8 & 8 & 5 & 7 & 6 & 10 \\
\hline Bank vegetative protection, right bank & 3 & 7 & 9 & 9 & 10 & 10 & 10 & 8 & 10 & 10 & 2 & 5 & 10 \\
\hline Bank stability, left bank & 8 & 9 & 8 & 9 & 10 & 10 & 10 & 7 & 10 & 8 & 9 & 7 & 10 \\
\hline Bank stability, right bank & 4 & 7 & 8 & 9 & 10 & 10 & 10 & 8 & 10 & 10 & 7 & 5 & 8 \\
\hline Riparian vegetative zone width, left bank & 9 & 9 & 10 & 7 & 10 & 8 & 10 & 5 & 8 & 1 & 8 & 5 & 10 \\
\hline Riparian vegetative zone width, right bank & 4 & 4 & 10 & 8 & 10 & 8 & 8 & 5 & 8 & 10 & 1 & 6 & 8 \\
\hline Total score & 155 & 164 & 170 & 157 & 199 & 191 & 182 & 165 & 185 & 179 & 147 & 155 & 192 \\
\hline
\end{tabular}

According to a habitat inventory report prepared by the U.S. Department of Agriculture (USDA) Forest Service, portions of the Geneva and Duck Creek subbasins contain marginal riparian zones (Winters and others, 1993). The USDA Forest Service study encompassed a much larger area than did the present study. The USDA Forest Service study indicated that Duck Creek had approximately 90 percent stable and vegetated banks consisting of willows and other shrubs. The study also indicated that the lower Duck Creek site had a high percentage of sand and silt in pool and glide habitats, which were upstream from the GC5 sampling area, indicating erosional impacts upstream from GC5. This fact could be due to beaver dams, which are occasionally breached during spring runoff and act as sediment traps, and (or) sediment from the disused Geneva Basin ski area. Active erosional areas also were identified near culverts.

The Geneva Creek habitat inventory determined that suitable habitat for biotic communities was limited on the left bank of Geneva Creek (Winters and others, 1993). The lack of habitat development may be due to the present location of the road, which generally runs parallel to Geneva Creek. Narrow strips of vegetation (10-15 ft wide) stabilized the left bank near the Geneva Creek Picnic Area. Recreational use on the right bank affected the habitat minimally. This location is equivalent to the GC11 site, which received a high habitat score (155) in the Guanella Pass study (fig. 4).
Table 7. Slope and percent gradient for each site, Guanella Pass study area

[ft/ft, foot per foot; \%, percent]

\begin{tabular}{lcc}
\hline Site & $\begin{array}{c}\text { Slope } \\
\text { (ft/ft) }\end{array}$ & $\begin{array}{c}\% \\
\text { gradient }\end{array}$ \\
\hline CC11 & 0.12 & 12 \\
CC9 & 0.05 & 5.3 \\
CC5 & 0.02 & 2 \\
CC2 & 0.16 & 16 \\
CC12 & 0.04 & 4.4 \\
CC1 & 0.16 & 16 \\
GC1 & 0.32 & 32 \\
GC2 & 0.16 & 16 \\
GC5 & 0.04 & 4 \\
GC7 & 0.04 & 4 \\
GC8 & 0.08 & 8 \\
GC10 & 0.16 & 16 \\
GC11 & 0.03 & 2.7 \\
DC1 & 0.07 & 6.7 \\
\hline
\end{tabular}

\section{Substrate Particle Size}

Wolman pebble counts are useful for characterizing the instream habitat (Wolman, 1954). Sites CC5, $\mathrm{CC} 2, \mathrm{GC} 2$, and DC1 had the highest percentage of sand (0.062 to 2-mm diameter) and smaller (less than 0.062-mm diameter) particles (table 8). All three of these sites are adjacent to gravel sections of the 
Table 8. Bed-material particle-size data from Wolman pebble counts at biological sampling sites, Guanella Pass study area

[>, greater than]

\begin{tabular}{lcllllllllll}
\hline \multirow{2}{*}{ Site } & \multicolumn{10}{c}{ Percentage finer than indicated particle size in millimeters } \\
\cline { 2 - 12 } & $\mathbf{2} 56$ & $\mathbf{2 5 6}$ & $\mathbf{6 4}$ & $\mathbf{8}$ & $\mathbf{4}$ & $\mathbf{2}$ & $\mathbf{1}$ & $\mathbf{0 . 5}$ & $\mathbf{0 . 2 5}$ & $\mathbf{0 . 1 2 5}$ & $\mathbf{0 . 0 6 2}$ \\
\hline CC11 & 99.98 & 72.98 & 42.98 & 7.98 & 5.98 & 5.61 & 4.19 & 2.44 & 1.08 & 0.39 & 0.11 \\
CC9 & 99.91 & 92.91 & 46.91 & 5.91 & 4.91 & 4.47 & 3.91 & 3.17 & 2.08 & 1.08 & 0.32 \\
CC5 & 99.53 & 97.53 & 80.53 & 14.53 & 11.53 & 10.36 & 9.19 & 8.18 & 6.53 & 4.08 & 1.4 \\
CC2 & 99.64 & 88.64 & 51.64 & 11.64 & 10.64 & 8.17 & 6.15 & 4.56 & 2.99 & 1.17 & 0.36 \\
CC12 & 99.35 & 90.55 & 51.15 & 3.65 & 3.65 & 3.52 & 2.92 & 2.3 & 1.81 & 1.26 & 0.56 \\
CC1 & 100 & 93 & 40 & 0 & 0 & 0 & 0 & 0 & 0 & 0 & 0 \\
GC1 & 99.96 & 80.96 & 56.96 & 7.96 & 7.65 & 4.03 & 2.02 & 1.2 & 0.73 & 0.06 & 0 \\
GC2 & 99.89 & 79.89 & 35.89 & 9.89 & 9.89 & 7.29 & 4.59 & 3.01 & 1.93 & 0.81 & 0.22 \\
GC5 & 99.64 & 72.64 & 44.64 & 7.64 & 6.64 & 6.38 & 6.03 & 5.28 & 3.15 & 1.59 & 0.59 \\
GC7 & 99.81 & 95.81 & 60.81 & 4.81 & 4.73 & 4.09 & 3.52 & 2.96 & 2.06 & 0.55 & 0 \\
GC8 & 99.99 & 88.99 & 44.99 & 2.99 & 2.99 & 2.71 & 2.04 & 1.46 & 0.93 & 0.3 \\
GC10 & 99.96 & 81.96 & 38.96 & 1.96 & 1.96 & 1.95 & 1.83 & 1.28 & 0.65 & 0.31 & 0.04 \\
GC11 & 99.9 & 71.9 & 28.9 & 2.9 & 2.9 & 2.56 & 2.13 & 1.54 & 0.97 & 0.67 & 0.27 \\
DC1 & 99.96 & 93.96 & 54.96 & 9.96 & 9.96 & 8.52 & 6.06 & 4.18 & 2.41 & 0.51 & 0.08 \\
\hline
\end{tabular}

Guanella Pass road. CC12 is located at a road runoffinflow point; however, particle-size distribution samples did not indicate an abundance of particles less than 2-mm diameter (3.52 percent). All of the sites had at least 90 percent of bed material that was equal to or greater than gravel-sized particles (greater than 2-mm diameter). This result indicates that substrate at the sampling sites generally was suitable for many macroinvertebrates, which prefer coarse materials.

\section{RESULTS OF MACROINVERTEBRATE AND ALGAL DATA ANALYSES}

\section{Macroinvertebrates}

Taxa Richness and Density. During the 3-year study, 100 macroinvertebrate taxa were identified ${ }^{2}$ from streams in the Guanella Pass study area. The taxonomic orders and number of taxa were Diptera (midges and other true flies), 55; Ephemeroptera (mayflies), 12; Plecoptera (stoneflies), 12; Trichoptera (caddisflies), 12; Coleoptera (beetles), 3; and others, 6 . The number of macroinvertebrate taxa in the Guanella Pass study area and reference sites ranged from 3 (GC7, WY95)

\footnotetext{
${ }^{2}$ Macroinvertebrates identified to family or genus level were not included in totals of taxa if organisms of those particular taxa also were identified to the genus or species level.
}

to 48 (GC10, WY96) taxa (fig. 5). Macroinvertebrate densities ranged from 6.6 to 4,300 organisms $/ \mathrm{m}^{2}$. Site GC7 had the lowest macroinvertebrate density during all 3 years (fig. 6). The sites with the highest densities varied from year to year: GC5 in WY95; GC1 and GC5 in WY96; and CC11 and GC5 in WY97. Although the density and taxa richness varied for each year, the same general patterns were present from year to year at many of the sites.

Shannon-Weaver Diversity Index. The index values for macroinvertebrates are representative of stream health and water quality; these values are expected to decrease in the downstream direction as contamination effects increase (Rosenberg and Resh, 1993). Guanella Pass streams did not follow this general rule, which can be attributed in part to the low primary productivity of headwater streams (Allan, 1995). Values in typical, uncontaminated mountain streams range between 3.0 and 4.0, and contaminated streams generally have values less than 1.0 (Ward and Kondratieff, 1992). The Shannon-Weaver diversity index was used to calculate diversity of the macroinvertebrate population at each site. Values ranged from 1.6 (GC7, WY95) to 4.5 (CC11 and DC1, WY96) (fig. 7). Sites GC7 (WY95-97) and GC1 (WY96) were the only sites that had a calculated value less than or equal to 3.0. With the exception of site GC7, diversity values on Guanella Pass were typical of values that are expected to occur in mountainous areas. 

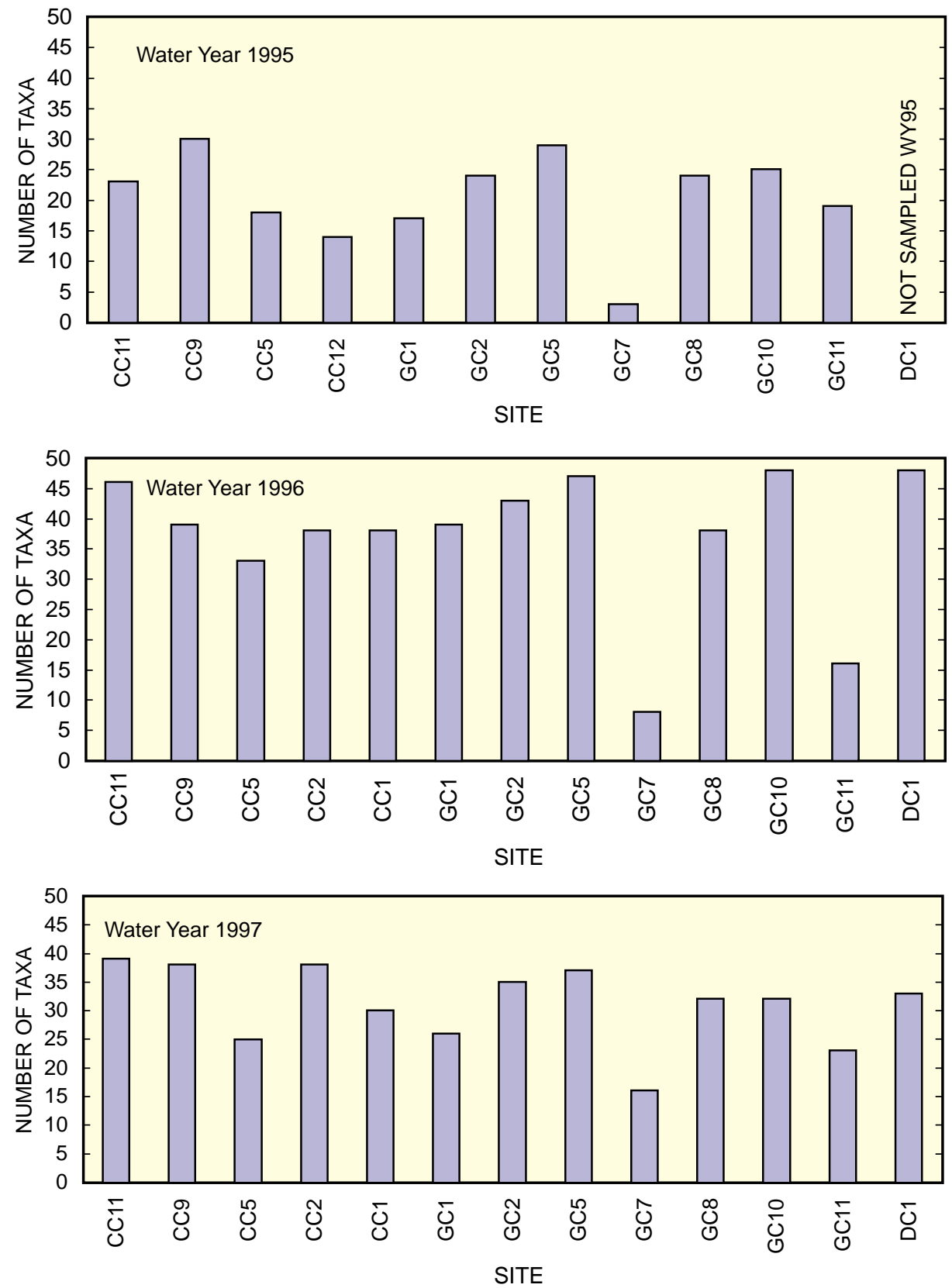

Figure 5. Total number of macroinvertebrate taxa in stream reaches, Guanella Pass study area, water years 1995-97. 

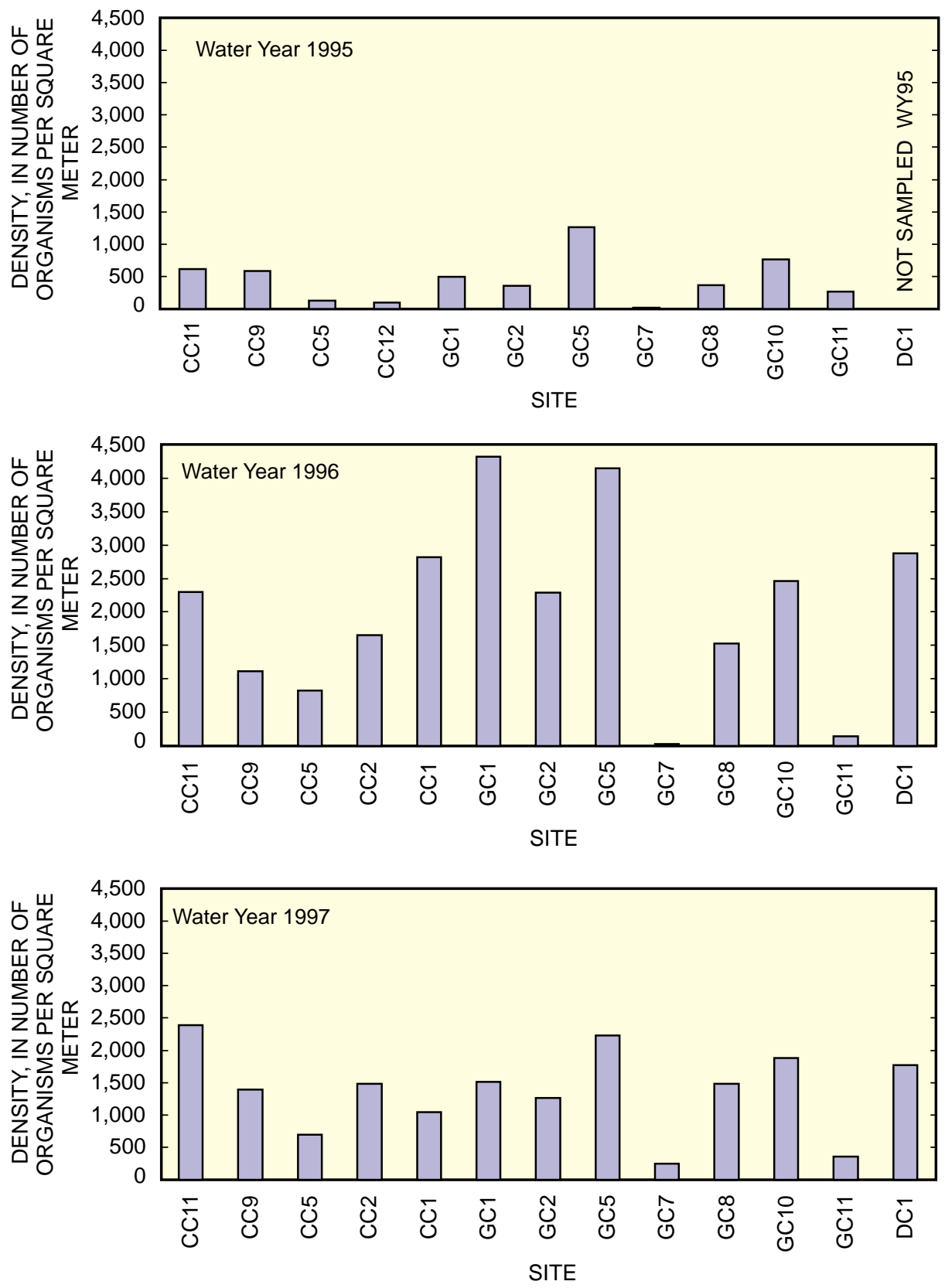

Figure 6. Macroinvertebrate density in stream reaches, Guanella Pass study area, water years 1995-97. 

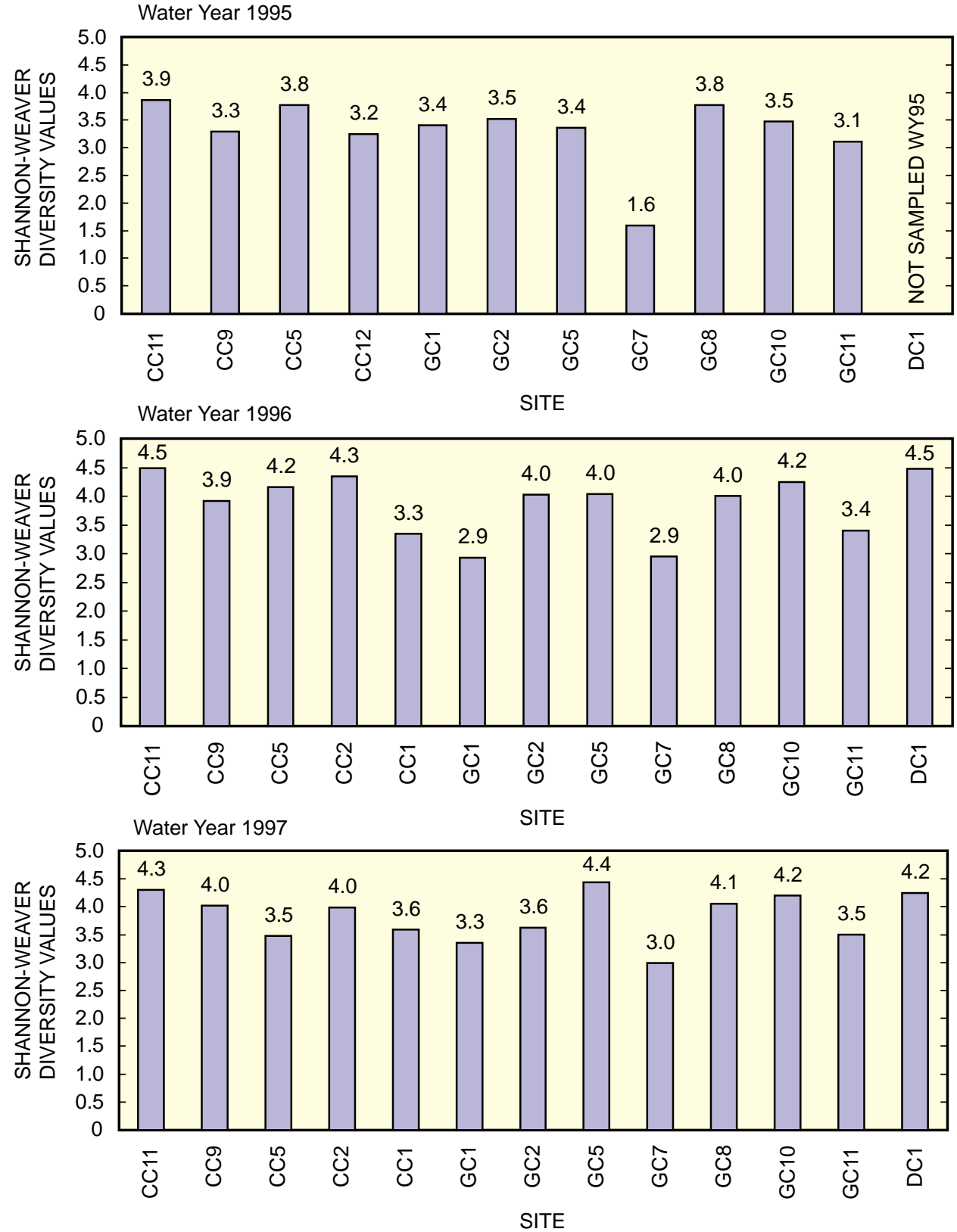

Figure 7. Shannon-Weaver diversity indexes for macroinvertebrates in stream reaches, Guanella Pass study area, water years 1995-97. 
Functional Feeding Group Measures. The dominant macroinvertebrate functional feeding groups of the Guanella Pass study area, in decreasing number of taxa, were collector-gatherers (34 taxa), predators (27), collectors (14), scrapers (9), shredders (8), and collector-filterers (6). These numbers reflect the overall taxa richness of the area. In terms of density, the three most dominant groups were collectorgatherers, predators, and shredders.

It is generally assumed that shredders predominate in headwater streams (Allan, 1995); however, that is not the case at all sites in the Guanella Pass study area. Shredders, which rely on microbes for a food source and are sensitive to toxicants and modifications in the riparian zone (Rosenberg and Resh, 1993), ranged in relative abundance from 0.64 (CC5, WY97) to 41.5 (GC2, WY95) (fig. 8), with an average of 9.7 percent for all sites during the 3 -year period. Because the growth rate of detrital-associated microbes decreases with decreasing temperature (Merritt and Cummins, 1996), the shredder populations may be hindered by the cool temperatures of the streams in the study area.

The dominance of collector-gatherers indicates a population of feeding generalists, which are usually regarded as pollution-tolerant because they have a broad selection of food resources they can exploit. Specialists, such as scrapers and shredders, are usually identified as pollution-sensitive groups since they rely on specific resources for their diet. Scrapers had significant populations at most sites (except GC7 and GC11 in 1996), indicating that the supply of diatoms and coarse-particulate matter is adequate to sustain these populations.

Ephemeroptera, Plecoptera, and Trichoptera (EPT). The number of EPT taxa at sampling sites ranged from 2 to 20 during the 3 -year period. The average relative abundance of EPT taxa at all sites during the 3-year period was 56.7 percent. Some of the highest values were measured at a few of the roadway sites, particularly at CC12 in 1995 and at GC11 for all 3 years (fig. 9). Because most sites had greater than 50 percent EPT individuals, it can be concluded that the streams support a robust population of pollutionintolerant macroinvertebrates.

EPT:Chironomidae. In 1995, all of the EPT:Chironomidae ratios were high (at least 2:1) on both sides of Guanella Pass (fig. 10). In 1996, four sites (CC1, GC1, GC2, and GC5) had a ratio that showed a greater prevalence of chironomids relative to the EPT taxa, which possibly indicates degraded conditions. This may indicate an environmental stress, possibly due to lower flows during the water year. Effects of low flow may include habitat loss and reduced dissolved-oxygen concentrations. In 1997, only one site, GC5, had a greater Chironomidae population than EPT. Generally, the populations in mountain streams should be skewed in favor of the pollution-intolerant EPT taxa. When the distribution is in favor of the chironomid population, the cause may be attributed to a pollution source such as increased metals or organic enrichment. The major factor for increased chironomids at sites on Guanella Pass probably is due to streamflow variation. Organic enrichment from cattle grazing in the vicinity may be affecting site GC5.

Community Similarity. Some of the similarity values are misleading because the calculation only recognizes those taxa that occur at both sites being compared. For example, if a site such as GC7 has very low abundance and is compared to another site that also has low abundance of similar taxa, the similarity value increases. This measure should be reviewed in the context of the other metrics. The similarity values ranged from 0 to 80 percent, excluding the 100 percent similarities from WY95 (table 9).

\section{Algae}

During the 3-year period, 280 algal taxa were identified in the study area: 253 diatoms (Bacillariophyta); 15 green algae (Chlorophyta); 9 blue-green algae (Cyanophyta); 2 euglenoids (Euglenophyta), which were identified only in 1995; and 1 species of red algae (Rhodophyta, identified only in 1996 and 1997). Diatom and non-diatom taxa were used to describe the community attributes.

Density. Algal densities vary with changes in water quality, but the number of cells cannot be directly correlated with environmental degradation (Stevenson and others, 1996). The density for each taxon was counted and reported as number of cells per square centimeter. The densities ranged from 306 cells $/ \mathrm{cm}^{2}$ (GC7, WY95) to more than $4.7 \times 10^{6}$ cells $/ \mathrm{cm}^{2}$ (GC1 and GC10, WY96; GC8, WY97) (fig. 11). Cyanophyta had the greatest density at most sites, followed by Chrysophyta, Chlorophyta, Euglenophyta, and Rhodophyta (fig. 12). 

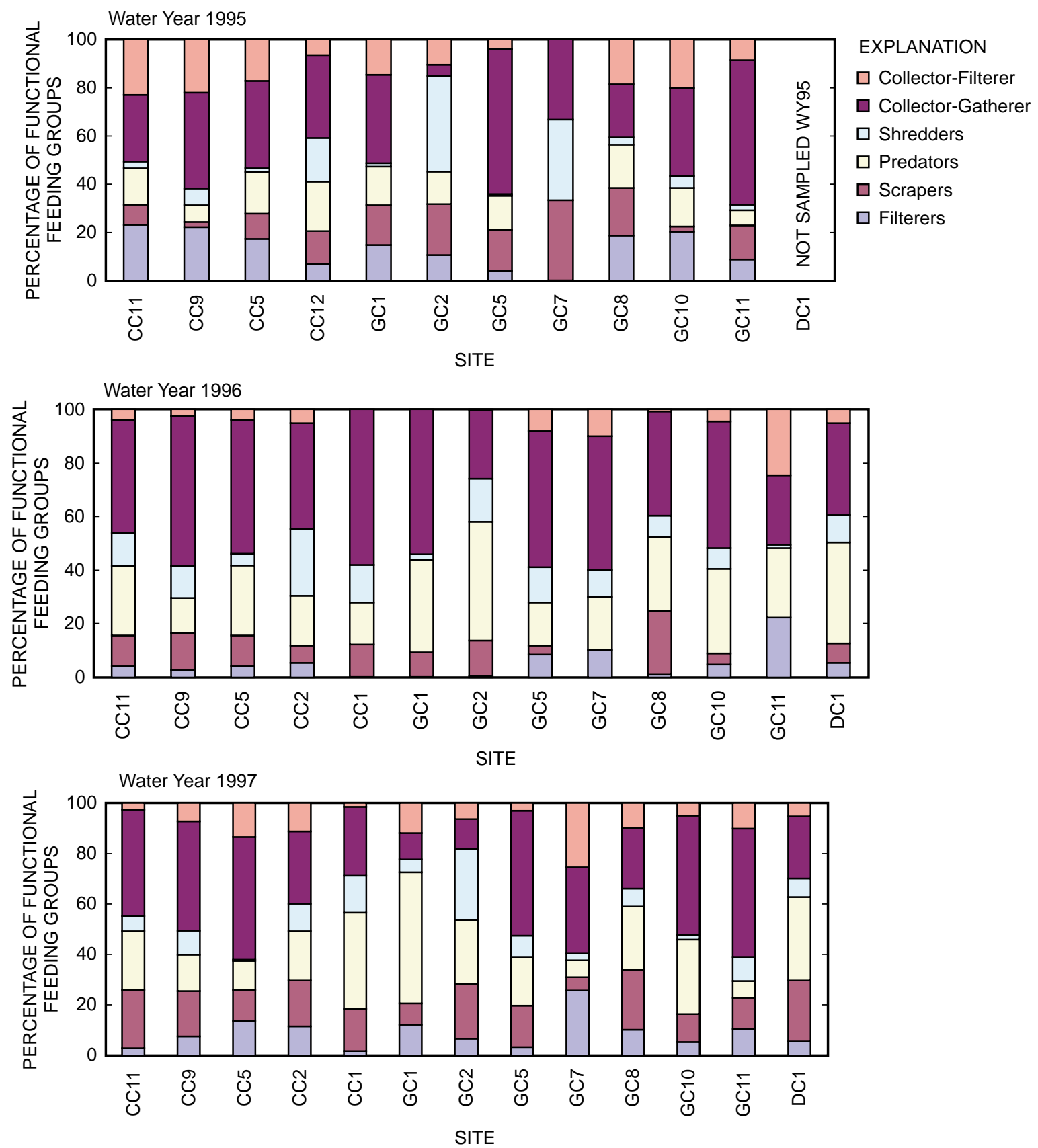

Figure 8. Relative abundance of macroinvertebrate functional feeding groups in stream reaches, Guanella Pass study area, water years 1995-97. 

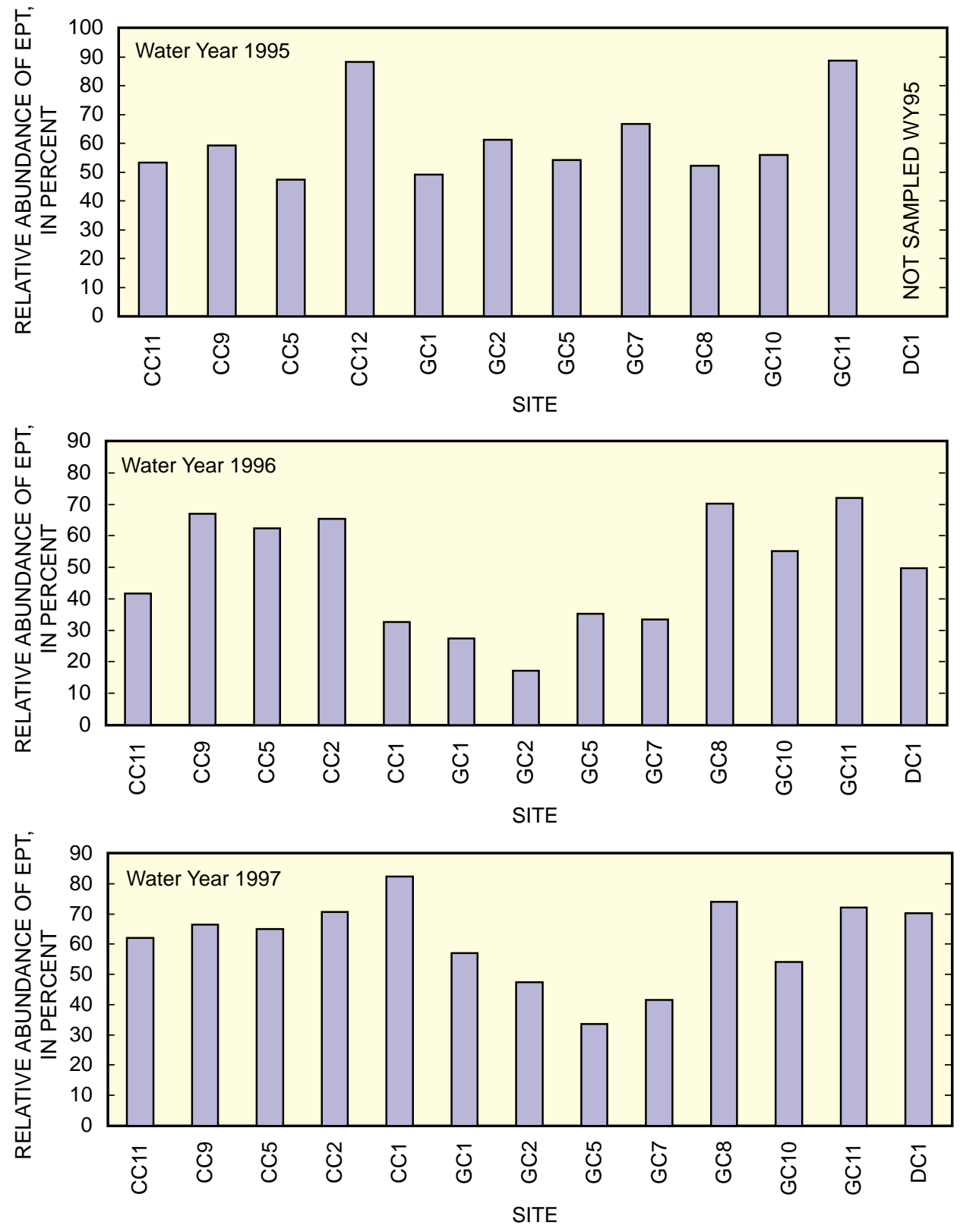

Figure 9. Relative abundance of Ephemeroptera, Plecoptera, and Trichoptera (EPT) in stream reaches of the Guanella Pass study area, water years 1995-97. 

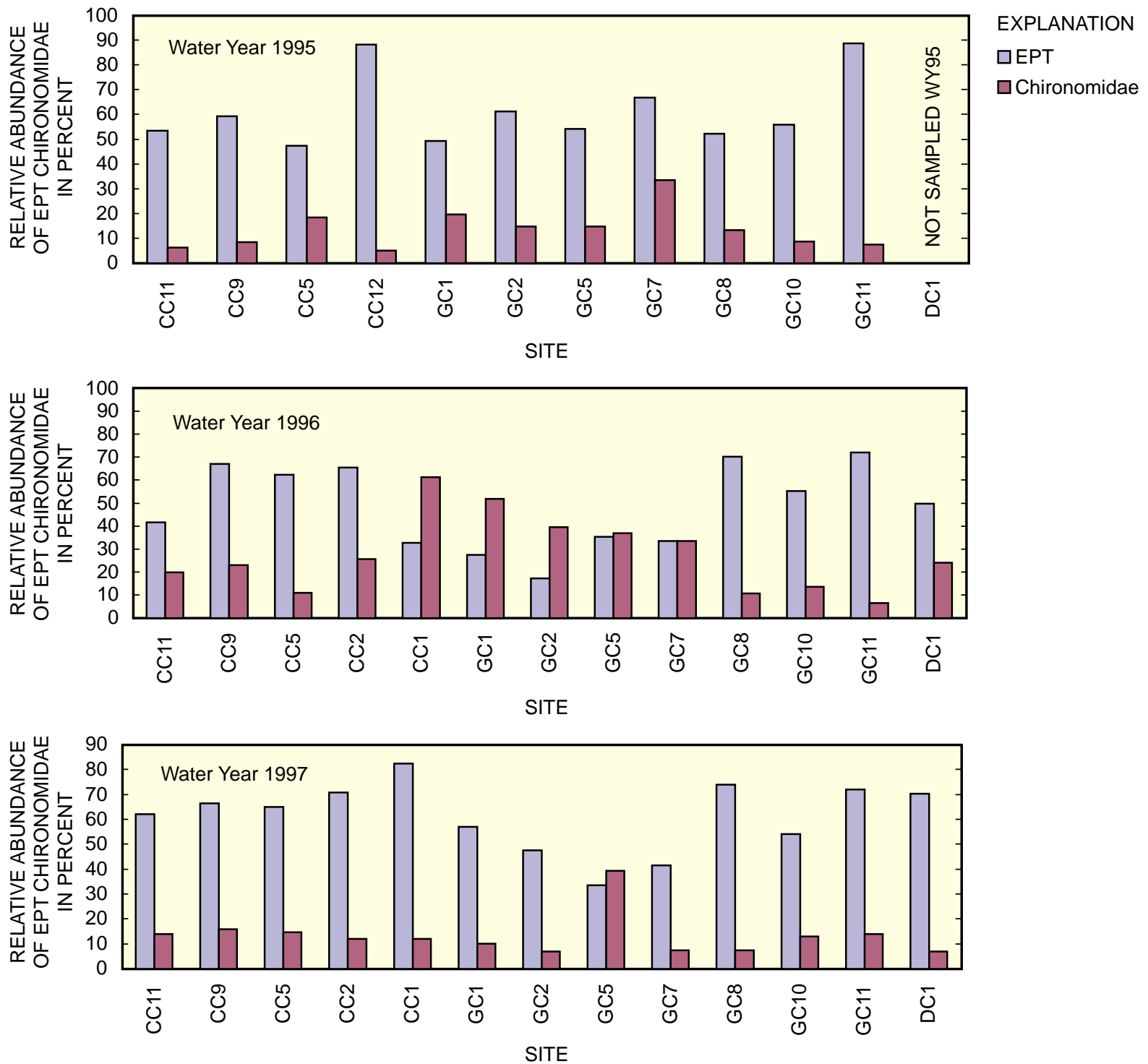

Figure 10. Relative abundance of EPT:Chironomidae in stream reaches of the Guanella Pass study area, water years 1995-97. 
Table 9. Percentage of community similarity of benthic macroinvertebrates at sites in the Guanella Pass study area, water years $1995-97$

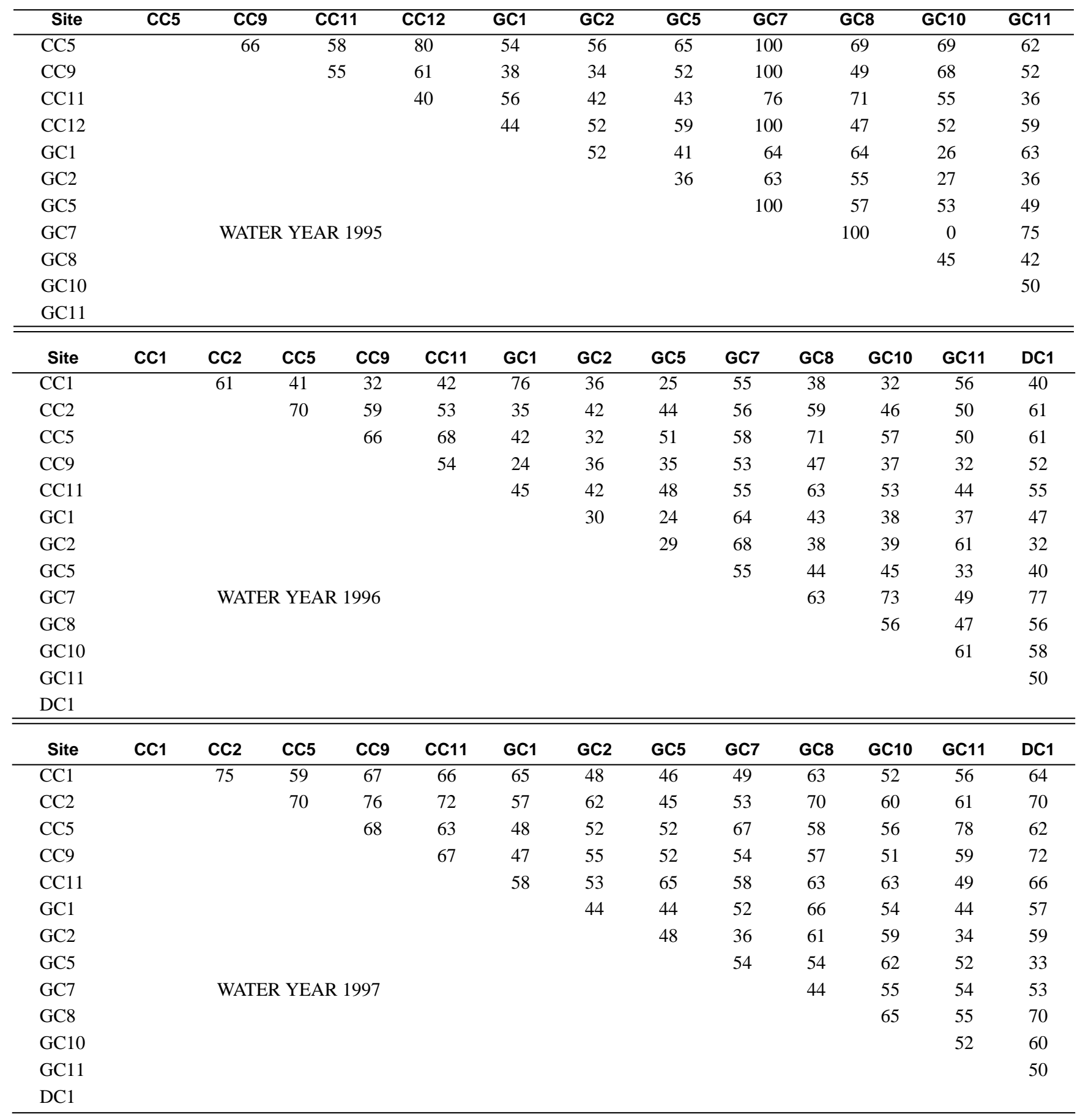

Biovolume. The biovolume of algal communities determines which species are dominant by identifying which cells occupy the most space (Stevenson and others, 1996) and, therefore, dominate the community structure. Biovolume ranged from
$2.3 \times 10^{4}$ cells $/ \mathrm{cm}^{3}(\mathrm{GC7}, \mathrm{WY} 95)$ to more than $4.6 \times 10^{9}$ cells $/ \mathrm{cm}^{3}$ (GC5, WY95) (fig. 13). Green algae (Chlorophyta) dominated at GC5 in WY95 and WY96, and blue-green algae (Cyanophyta) were dominant at this site in WY97 (fig. 14). 

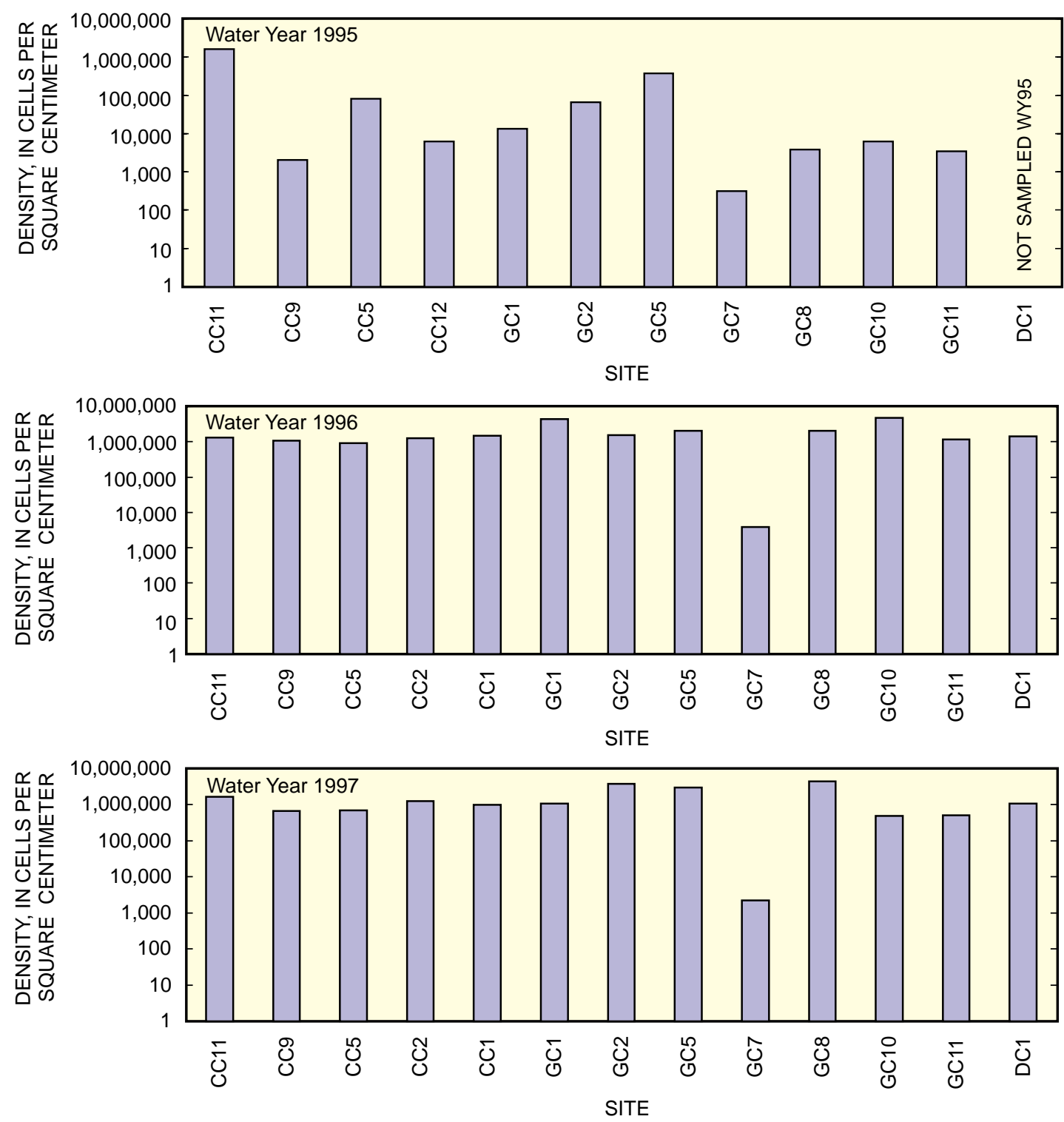

Figure 11. Algal density in stream reaches, Guanella Pass study area, water years 1995-97. 

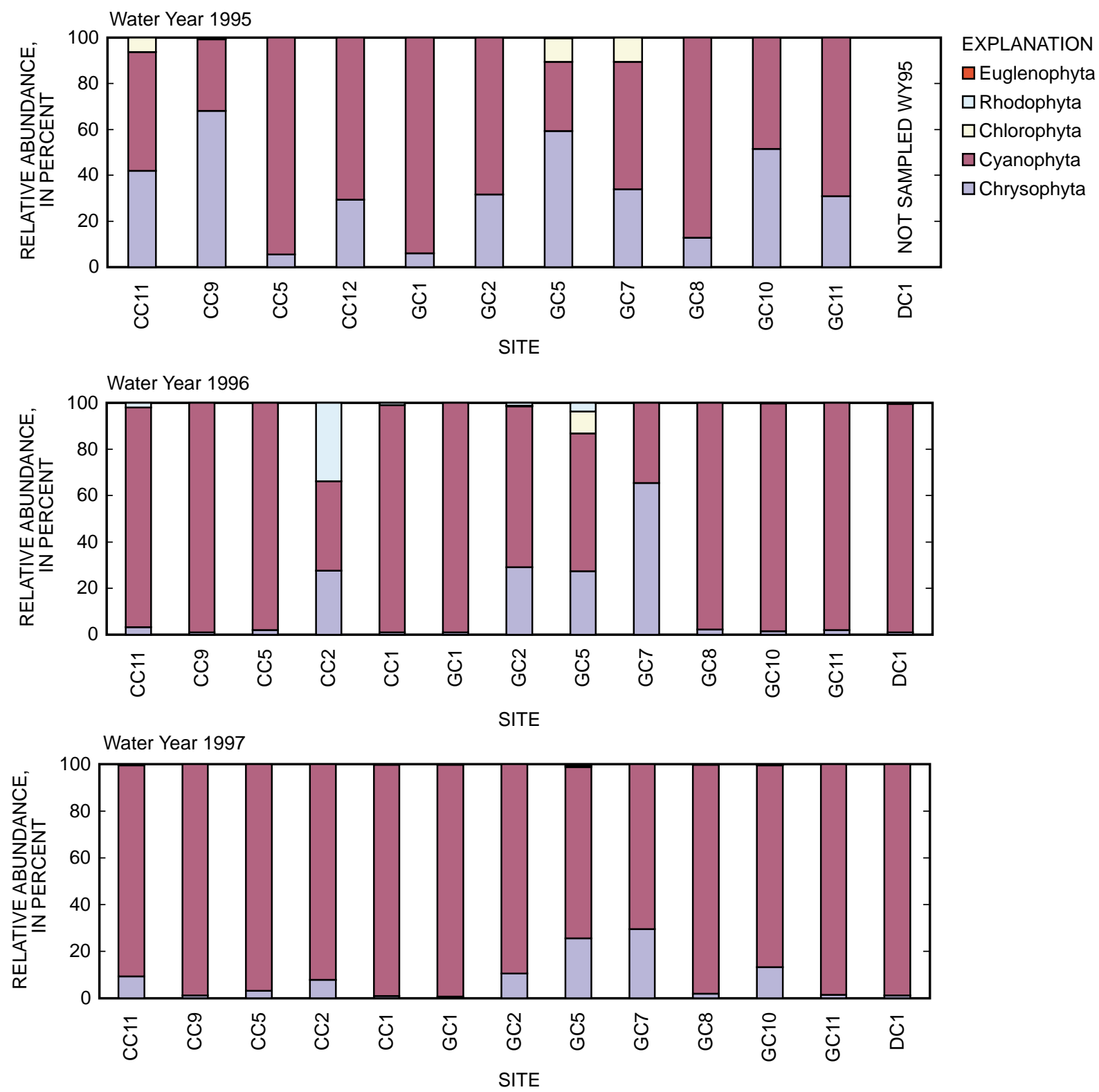

Figure 12. Relative abundance of algal divisions, Guanella Pass study area, water years 1995-97. 

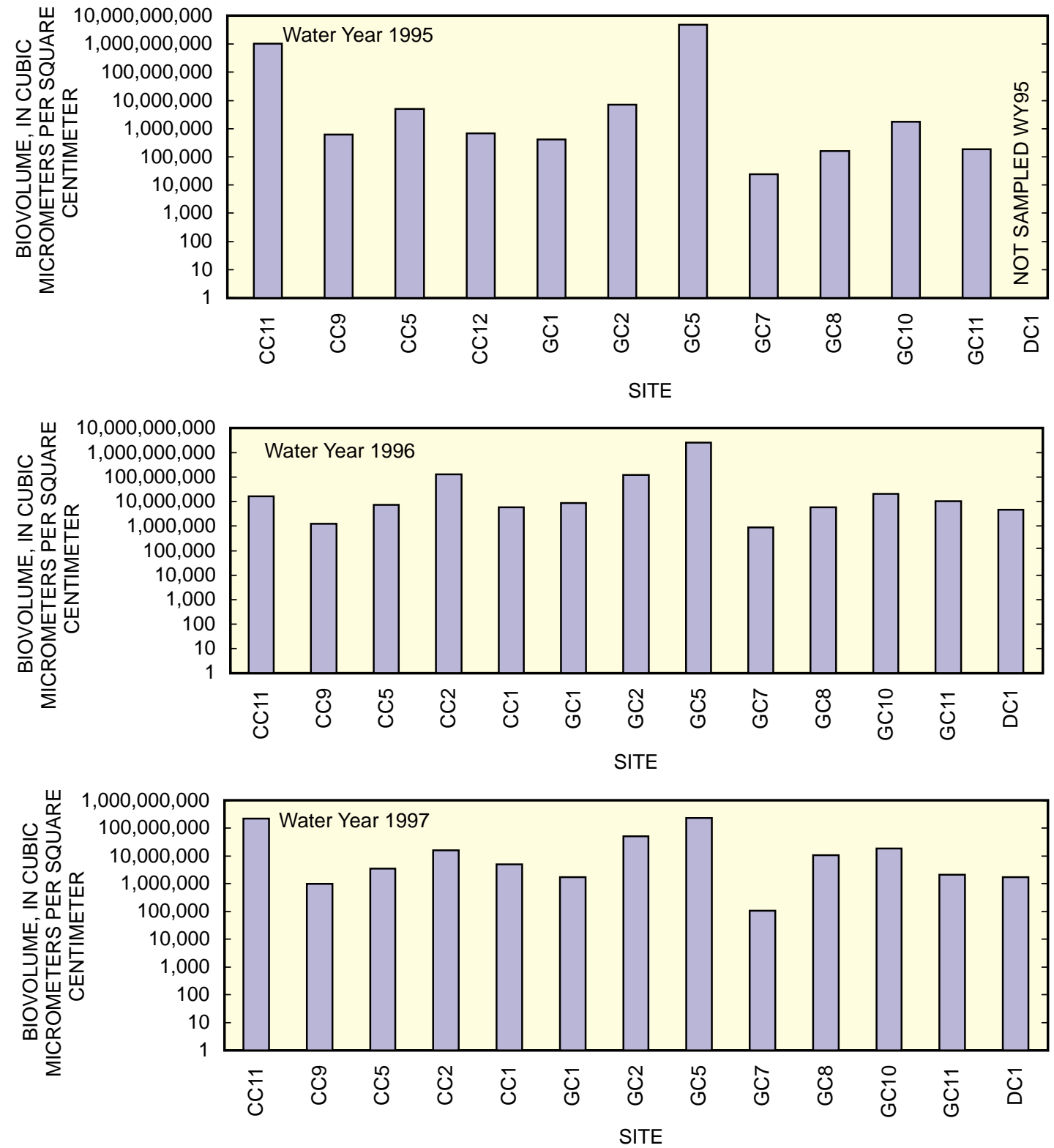

Figure 13. Algal biovolume in stream reaches, Guanella Pass study area, water years 1995-97. 

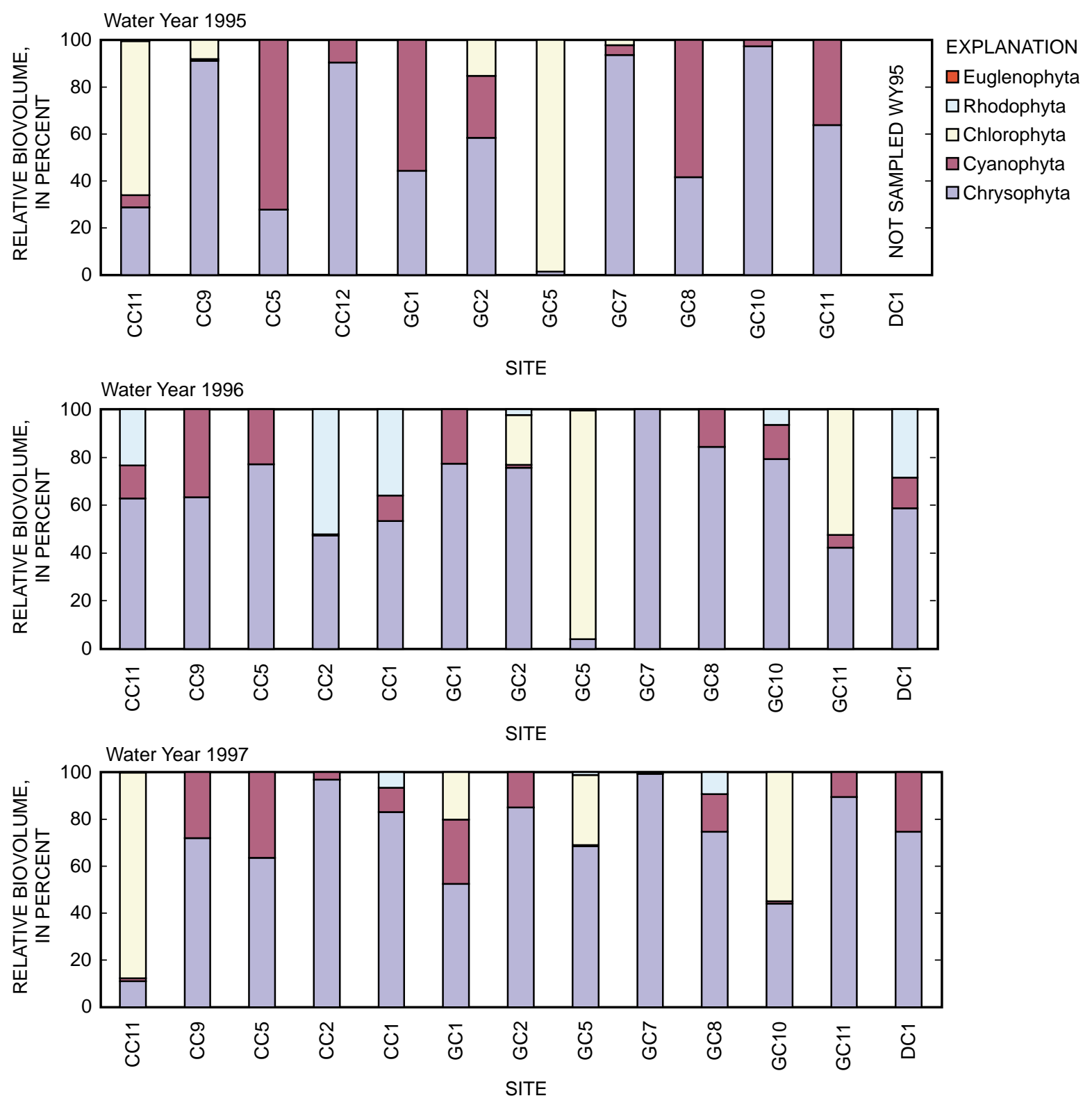

Figure 14. Relative biovolume of algal divisions, Guanella Pass study area, water years 1995-97. 
Diatoms dominated at the rest of the sites each year. The dominance of diatoms in the study area is typical of mountain streams. Fine-sized substrate and warm temperatures at GC5 created conditions that support the dominance of green and blue-green algae (Stevenson and others, 1996). In general, the dominance of diatoms at most sites is expected because these taxa thrive in cooler temperatures $\left(5-20^{\circ} \mathrm{C}\right)$ and on stable, embedded substrate (Allan, 1995). Red algae (Rhodophyta) and Euglenoids had the lowest biovolumes.

Diversity. This calculation is used because algal communities are sensitive to water-quality changes, and changes in species diversity may be a useful indicator of changes in water quality (Plafkin and others, 1989). In general, the more polluted a system is, the lower the species diversity. Diversity values for WY95-97 ranged from 1.5 to 4.9 (fig. 15). The average values were between 3.0 and 3.3, which are similar to average diversity values in the Rocky Mountains (Metzmeier, 1994). The highest diversity values (approximately 4.5) in 1995 were measured at GC5 and GC7; the lowest values (approximately 1.8) were measured at GC1 and GC11. In WY96 and WY97, the highest diversity values were measured at GC5 and GC7. In WY96, the lowest value was at CC9; in WY97, the lowest value was at GC10. In general, the diversity scores were within an average range that is expected in mountain area streams.

Pollution Tolerance Index (PTI) for Diatoms. The PTI values ranged from 1.8 to 3.0; 1 represents the most pollution-tolerant communities and 3 represents the least pollution-tolerant communities. In WY95, the PTI values for diatoms ranged from 1.8 (CC12) to 2.8 (GC11) (fig. 16). The values increased in a downstream direction at all sites associated with the road. In WY96, the values ranged from 2.7 ( $\mathrm{GC} 7$ and $\mathrm{GC} 2$ ) to 3.0 (CC9 and $\mathrm{GC} 1$ ). Values increased in a downstream direction on both sides of Guanella Pass at sites adjacent to the road. In WY97, the PTI values ranged from 2.1 (CC5) to 2.9 (CC9, GC10, and DC1). At sites located on the south side of Guanella Pass, the PTI values decreased in the downstream direction, whereas at sites located on the north side, the values decreased between GC2 and GC5 and increased at GC11. The PTI values for most sites did not indicate that pollution was affecting the overall stream health (Bahls, 1992).

Percentage of Sensitive Diatoms. In WY95, the percentage of sensitive diatoms ranged from 34.1 (CC12) to 84.5 (GC1) (fig. 17). At sites located on the north side of Guanella Pass, the relative abundance of sensitive diatoms increased in a downstream direction between $\mathrm{CC} 12$ and CC5. At sites on the south side of the pass, the percentage of sensitive diatoms increased in the downstream direction at sites associated with the gravel sections of road (GC2 and GC11). In WY96, the percentage of sensitive diatoms ranged from 69.7 (GC2) to 96.5 (GC1). At sites on the north side of the pass, the percentage of sensitive diatoms increased in a downstream direction between $\mathrm{CC} 2$ and CC5, a section of gravel road. On the south side of the pass, the percentage increased at each successive downstream site, although there was very little difference between GC5 and GC11. In WY97, the percentage of sensitive diatoms ranged from 21 percent (CC5) to 97 percent (GC10). The distribution of sensitive diatoms in 1997 did not show a pattern of decreasing or increasing between successive downstream sites. Sensitive diatoms greater than 50 percent were observed at most sites each year, which indicates that the water quality is adequate to sustain these populations.

Percentage of Motile Diatoms. The population of motile diatoms was a substantial (greater than or equal to 5 percent relative abundance) at only three sites in WY95: CC9 (13 percent), CC5 (7.9 percent), and GC10 (5 percent) (fig. 18). All of these sites are adjacent to the Guanella Pass road. In WY96, there were few differences between sites; the percentage of motile diatoms ranged from 0 percent (all sites except GC5 and GC7) to 4.2 percent at GC7. The percentage of motile diatoms decreased even more in WY97, and only three sites (CC5, GC5, and GC7) had greater than 0.5 percent. The low relative abundance at all of the sites indicates that there may not have been a problem with sedimentation during WY96-97.

\section{Relative Abundance of Acid-Tolerant}

Diatoms. Diatoms have optimal $\mathrm{pH}$ ranges in which they can survive; therefore, the presence of acid-tolerant diatoms can be used to infer the $\mathrm{pH}$ of streams. Most of the sites had background values (Stephen Porter, U.S. Geological Survey, oral commun., 1997) of less than 5 percent acid-tolerant diatoms (fig. 19); GC7, a site with measured acidic $\mathrm{pH}$, had the most consistent population of acid-tolerant diatoms with greater than 19 percent each year. Consistent acidic conditions are not prevalent at the other sites on Guanella Pass. 

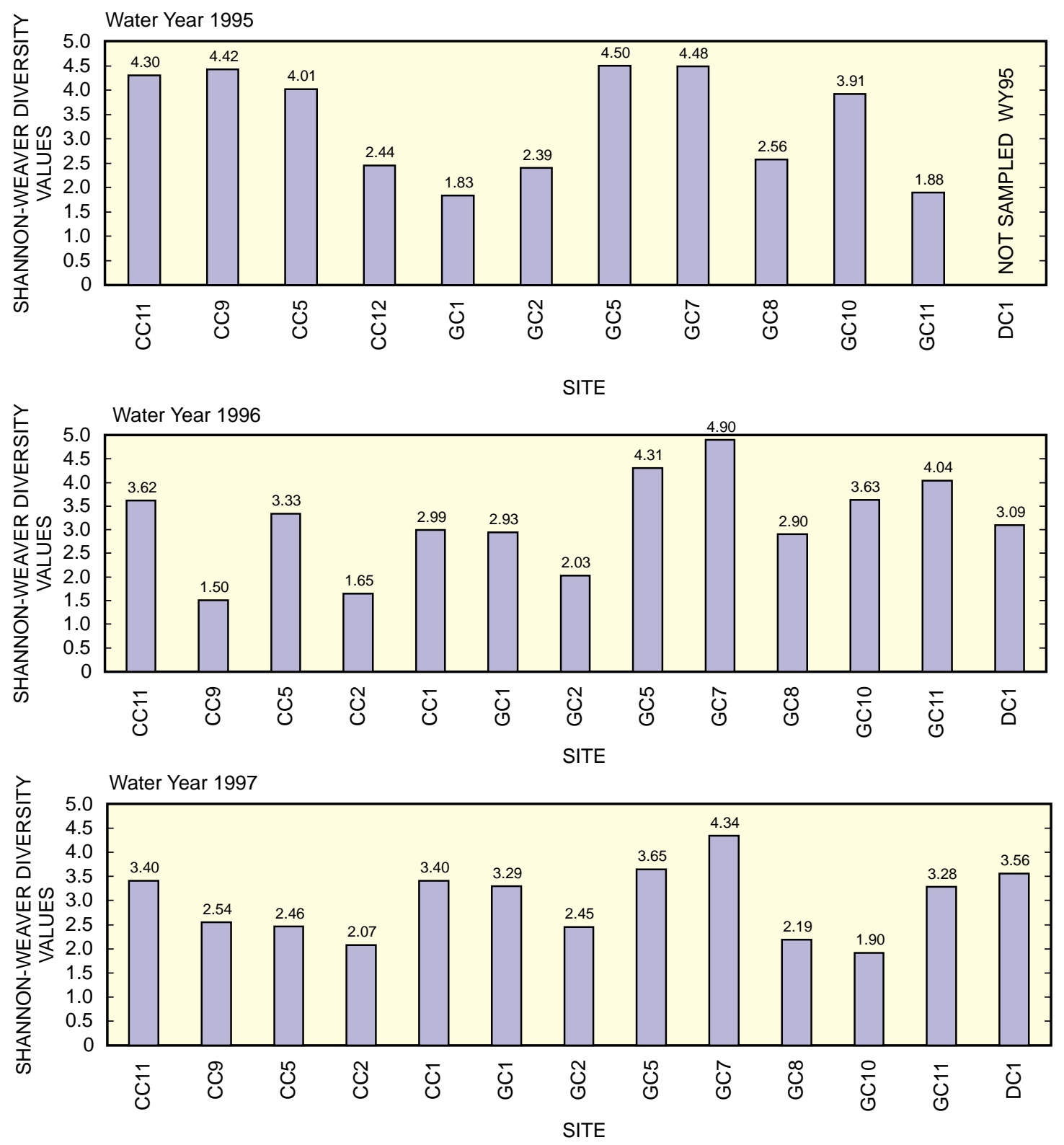

Figure 15. Shannon-Weaver diversity index for diatoms in stream reaches, Guanella Pass study area, water years 1995-97. 

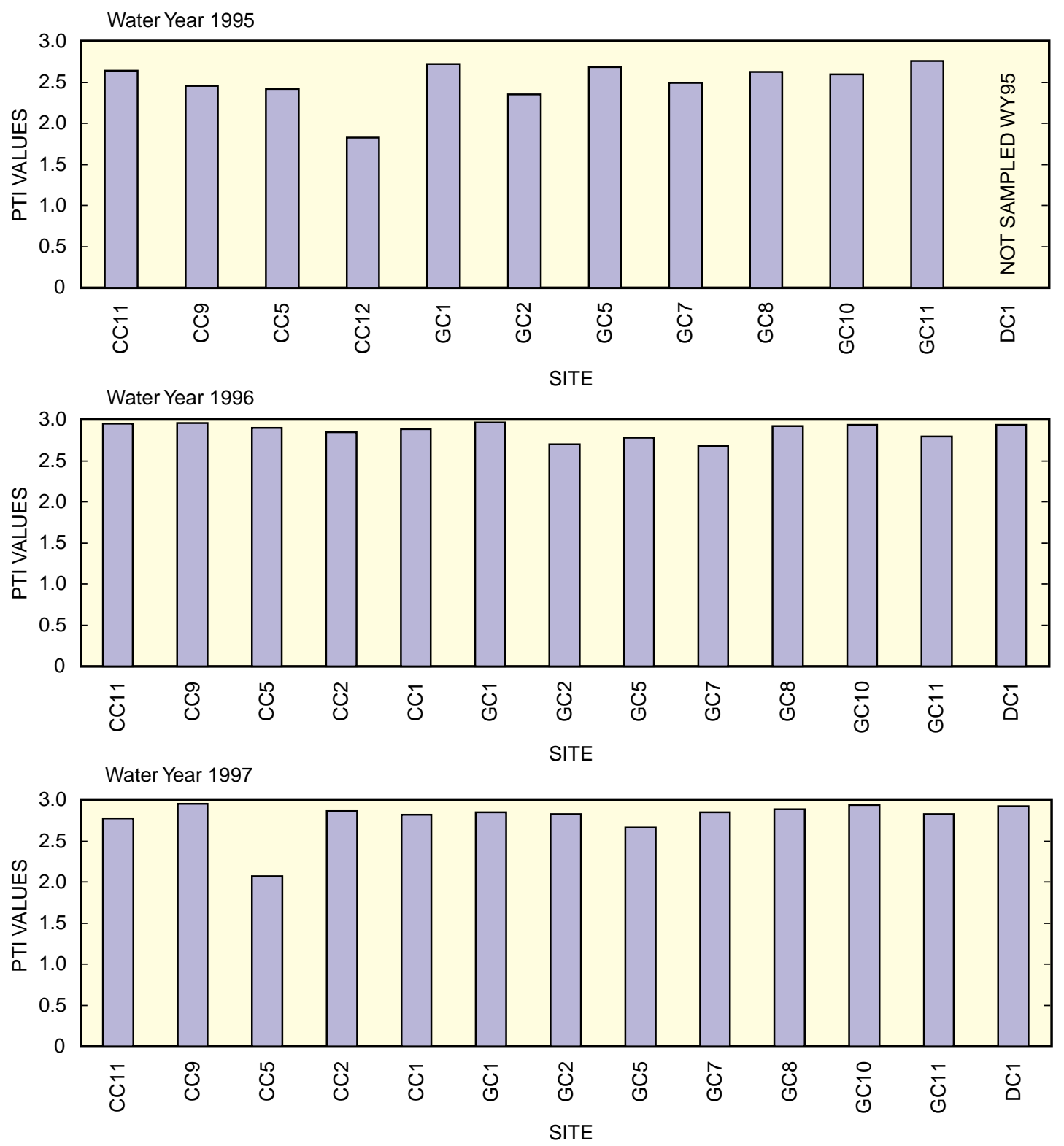

Figure 16. Pollution Tolerance Index (PTI) for diatoms in stream reaches of the Guanella Pass study area, water years 1995-97. 

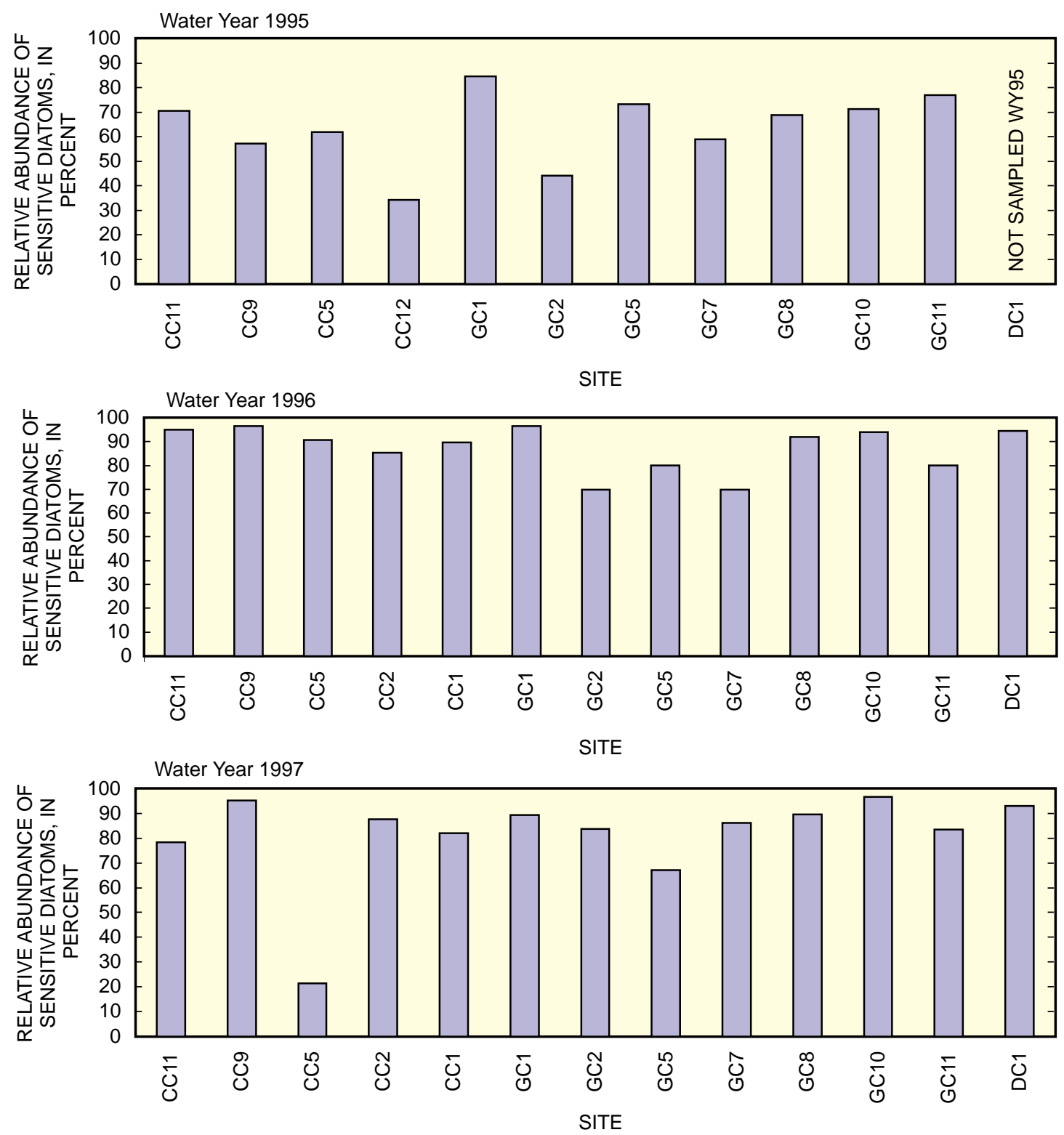

Figure 17. Relative abundance of sensitive diatoms in stream reaches, Guanella Pass study area, water years 1995-97. 


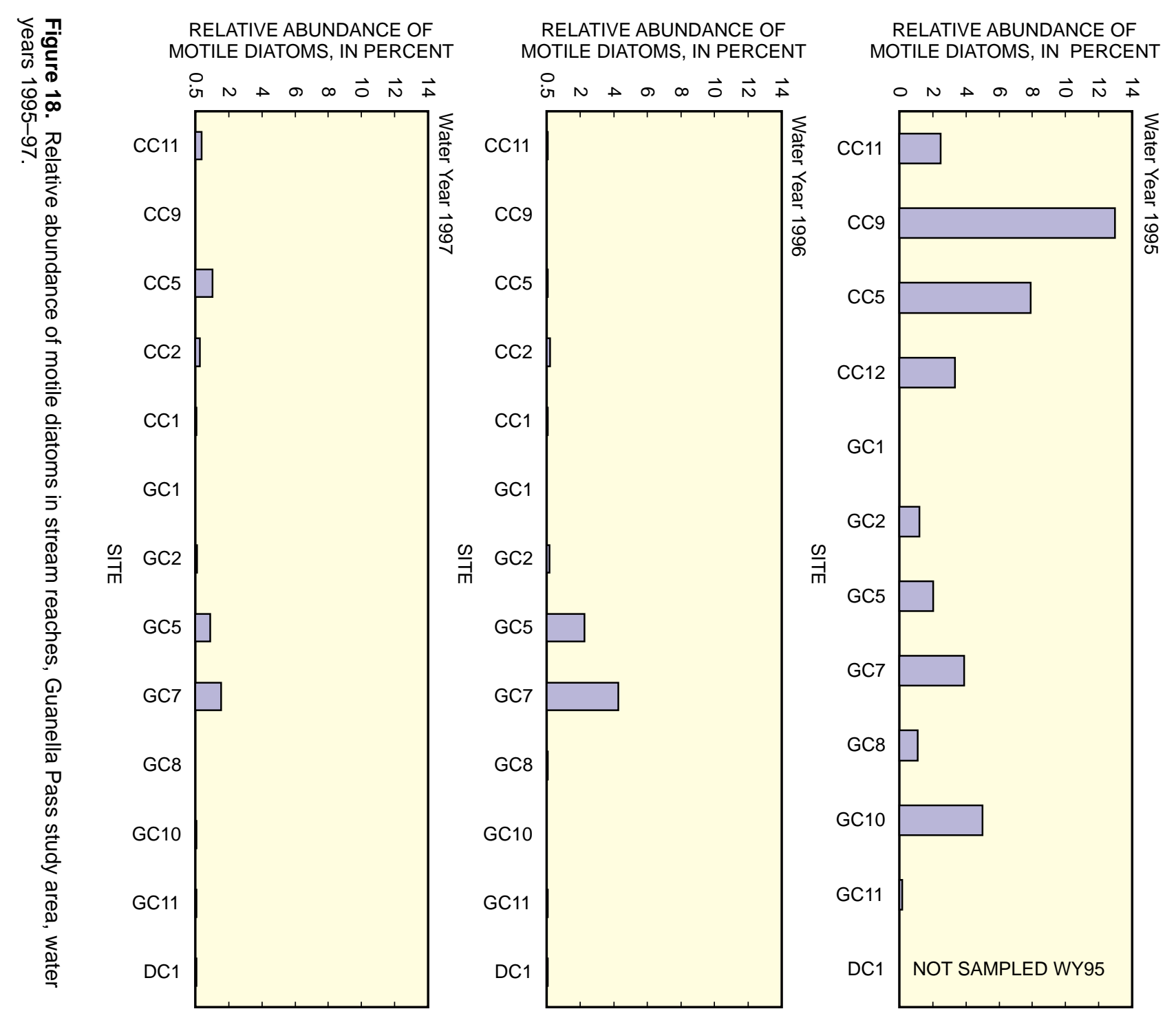



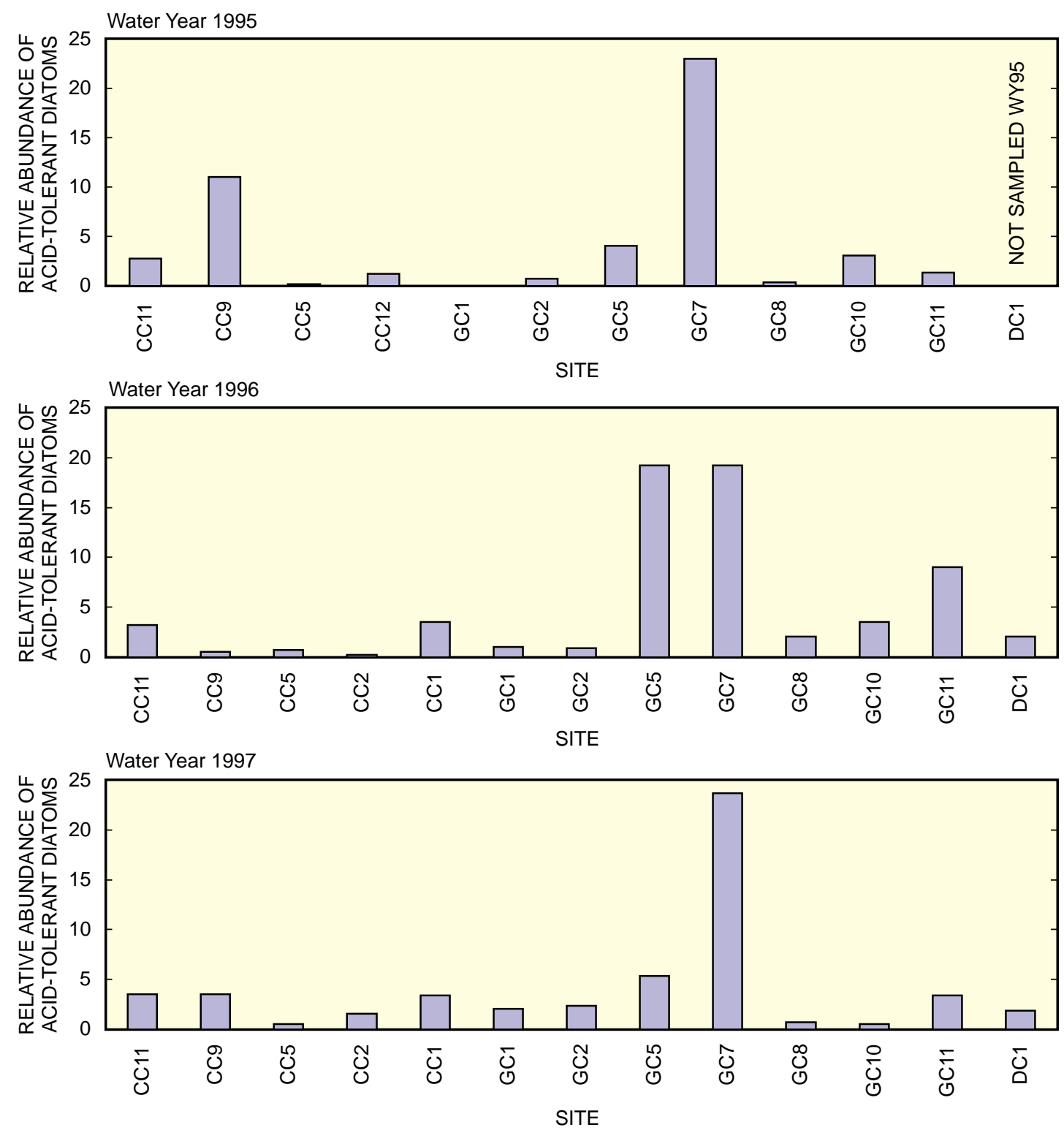

Figure 19. Relative abundance of acid-tolerant diatoms in stream reaches, Guanella Pass study area, water years 1995-97. 
Percentage of Community Similarity $\left(P S_{c}\right)$. $P S_{c}$ describes the similarity of common taxa between site pairs and gives weight to dominant taxa (Plafkin and others, 1989). $P S_{c}$ values ranged from 1 percent
(GC2 compared to GC1, WY95) to 97 percent (CC1 compared to DC1, WY96, and GC11, WY97) when all sites were compared to each other (table 10).

Table 10. Percentage of community similarity of algal abundance at sites in the Guanella Pass study area, water years $1995-97$

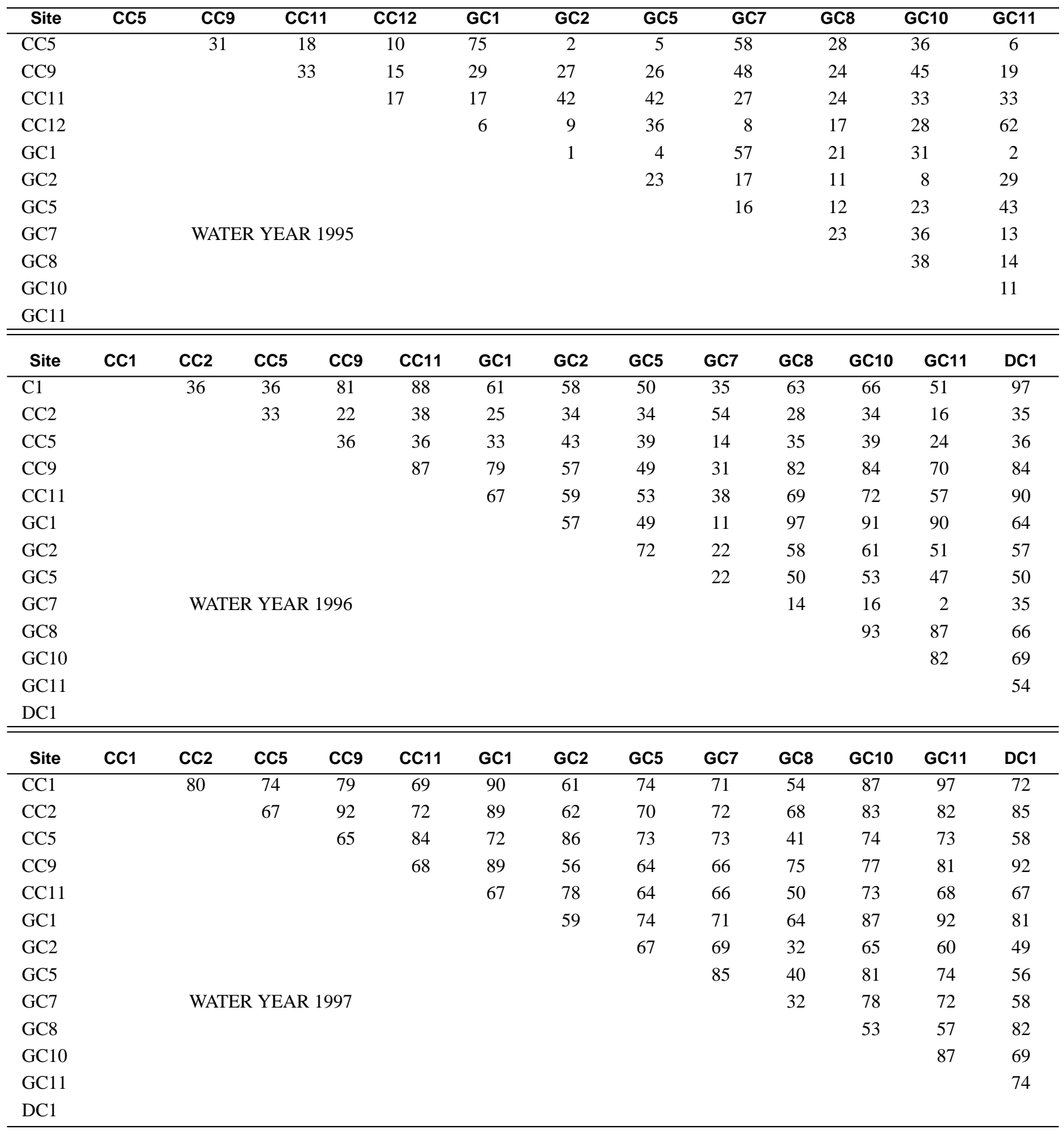




\section{SUMMARY AND CONCLUSIONS}

Biological samples were collected from the Guanella Pass study area during a 3-year period (WY95-97) during summer, low-flow conditions. The purpose of this study was to characterize biotic conditions for streams in the Guanella Pass area prior to proposed road-reconstruction activity. Biomonitoring was used to evaluate the overall quality of streams because biological communities are sensitive to short- and long-term changes in the environment. The results from this study will be used as baseline data for possible future studies in the area.

Specific conductance was relatively constant during the 3-year period. The values for $\mathrm{pH}$ were neutral in this study and showed little variation among sites except at GC7 (pH 4.0-7.2). Suspended-sediment concentrations were highest at $\mathrm{CC} 2$, which also had the greatest range during the sampling period ( 0 to greater than $1,000 \mathrm{mg} / \mathrm{L}$ ). The highest turbidities (500-1,000 NTU) were recorded at sites that were adjacent to the road: CC2 and CC5. Overall, nutrient concentrations (nitrogen and phosphorus) were low at all sites; thus, these are possible limiting factors for primary productivity.

\begin{tabular}{|c|c|}
\hline Metric & Range of values (site, year) \\
\hline $\begin{array}{l}\text { Macroinvertebrate taxa } \\
\text { richness }\end{array}$ & 3 (GC7, WY95) to 48 taxa (GC10, WY96) \\
\hline $\begin{array}{l}\text { Macroinvertebrate } \\
\text { density }\end{array}$ & $\begin{array}{l}\text { 6.6 (GC7, WY95) to } 4,300 \text { organisms } / \mathrm{m}^{2} \\
\quad(\mathrm{GC} 1, \mathrm{WY} 96)\end{array}$ \\
\hline $\begin{array}{l}\text { Shannon-Weaver } \\
\text { diversity for } \\
\text { macroinvertebrates }\end{array}$ & $\begin{array}{l}\text { 1.6 (GC7, WY95) to } 4.5 \text { (CC11 and DC1, } \\
\text { WY96) }\end{array}$ \\
\hline $\begin{array}{l}\text { Ephemeroptera, } \\
\text { Plecoptera, and } \\
\text { Trichoptera (EPT) } \\
\text { taxa }\end{array}$ & $\begin{array}{l}2 \text { (GC7, WY95) to } 20 \text { (GC10, WY96; } \\
\text { GC8 and DC1, WY97) }\end{array}$ \\
\hline Chironomids & $\begin{array}{l}\text { More numerous at CC1, GC1, GC2, GC5, } \\
\text { WY96, than other sites }\end{array}$ \\
\hline Algal density & $\begin{array}{c}306 \text { cells } / \mathrm{cm}^{2}(\mathrm{GC} 7, \text { WY95) to more than } \\
4.7 \times 10^{6} \text { cells } / \mathrm{cm}^{2}(\mathrm{GC} 10 \text {, WY96) }\end{array}$ \\
\hline Algal biovolume & $\begin{array}{l}2.3 \times 10^{4} \text { cells } / \mathrm{cm}^{3}(\mathrm{GC} 7, \text { WY95) to more } \\
\text { than } 4.6 \times 10^{9} \text { cells } / \mathrm{cm}^{3}(\mathrm{GC} 5, \text { WY95) }\end{array}$ \\
\hline $\begin{array}{l}\text { Pollution Tolerance } \\
\text { Index (PTI) for } \\
\text { diatoms }\end{array}$ & $\begin{array}{l}1.8 \text { (CC12, WY95) to } 3.0 \text { (CC9 and GC1, } \\
\text { WY96) }\end{array}$ \\
\hline $\begin{array}{l}\text { Percentage of sensitive } \\
\text { diatoms }\end{array}$ & 21 (CC5, WY97) to 97 (GC10, WY97) \\
\hline $\begin{array}{l}\text { Percentage of motile } \\
\text { diatoms }\end{array}$ & $\begin{array}{l}\text { less than } 0.5 \text { (CC9, GC1, GC10, WY96; } \\
\text { CC9, GC1, GC8, WY97) to } 13 \text { (CC9, } \\
\text { WY95) }\end{array}$ \\
\hline $\begin{array}{l}\text { Percentage of acid- } \\
\text { tolerant diatoms }\end{array}$ & less than 5 to 24 (GC7, WY97) \\
\hline
\end{tabular}

Differences in biotic conditions between sites were few, with the exception of $\mathrm{CC} 12$ and GC7. The differences observed between $\mathrm{CC} 12$ and GC7 and the other sites can be accounted for when the environmental factors, such as habitat, are examined. Because of its proximity to the road and the relatively low gradient (4.4) of the stream reach, site $\mathrm{CC} 12$ could be a potentially important monitoring site during road construction. Future sampling could include samples collected directly upstream and downstream from the erosional area for comparison with sites upstream and downstream from CC12. This information could be used in conjunction with the percentage of contributing road runoff to predict how future construction might affect the stream.

The GC7 site had the most degraded biological condition, as indicated by macroinvertebrate and algal metrics, when compared to other reference sites in the Guanella Pass area. The downstream effects of acid-sulfate weathering, which affects GC7, are evident as far downstream as GC11. The macroinvertebrate densities, algal densities, and biovolumes are much higher at GC11 than at GC7; however, GC11 does not seem to sustain a healthy biotic community, according to the calculated metrics, relative to the rest of the study area. Algal and macroinvertebrate metrics may have overestimated stream health at these sites because the biotic populations were not abundant. Duck Creek (GC1, GC2, and GC5) and Bruno Gulch (GC8), tributaries to Geneva Creek (GC7 and GC11), have relatively healthy community structures. The degraded condition of Geneva Creek is probably due to natural effects from natural acid-sulfate weathering, as opposed to road effects. Although CC2 is located downstream from several sources of road runoff, the biological community at this site does not seem to be negatively affected.

Esthetically, there are some places, especially below erosional areas, where riparian and instream habitat are degraded, which indicates that the erosion may cause some localized effects but may not affect the overall health of the whole stream system. According to the biotic metrics evaluated during this study, the macroinvertebrate and algal communities in the streams on Guanella Pass are not degraded. 


\section{REFERENCES}

Allan, J.D., 1995, Stream ecology-Structure and function of running waters: Great Britain, Chapman and Hall, 388 p.

American Public Health Association, American Water Works Association, and Water Environment Federation, 1992, Standard methods for the examination of water and wastewater (18th ed.): Washington, D.C., American Public Health Association.

Bahls, L.L., 1992, Periphyton bioassessment methods for Montana streams: Helena, Montana, Department of Health and Environmental Sciences, Water Quality Bureau, $34 \mathrm{p}$.

Bassett, R.L., Miller, W.R., McHugh, J.B., and Catts, J.G., 1992, Simulation of natural acid sulfate weathering in an alpine watershed: Water Resources Research, v. 28, no. 9, p. 2197-2209.

Brower, J.E., and Zar, J.H., 1984, Field and laboratory methods for general ecology: Dubuque, Iowa, Brown Publishers, 266 p.

Cline, L.D., Short, R.A., and Ward, J.V., 1982, The influence of highway construction on the macroinvertebrates and epilithic algae of a high mountain stream: Hydrobiologia, v. 96, p. 149-159.

Cline, L.D., Short, R.A., Ward, J.V., Carlson, C.A., and Gary, H.L., 1983, Effects of highway construction on water quality and biota in an adjacent Colorado mountain stream: United States Department of Agriculture Forest Service Research Note RM-429, 12 p.

Colorado Climate Center, 1984, Colorado average annual precipitation map, 1951-1980: Fort Collins, Colorado Climate Center, scale 1:500,000.

Cuffney, T.F., Gurtz, M.E., and Meador, M.R., 1993, Methods for collecting benthic macroinvertebrate samples as part of the National Water-Quality Assessment Program: U.S. Geological Survey Open-File Report 93-125, 217 p.

Davis, M.W., and Streufert, R.K., 1990, Gold occurrences of Colorado: Colorado Geological Survey Resource Series 28, $101 \mathrm{p}$.

Edmunds, G.F., Jr., Jensen, S.L., and Berner, L., 1976, The mayflies of North and Central America: Minneapolis, University of Minnesota Press, $330 \mathrm{p}$.

Edwards, T.K., and Glysson, G.D., 1988, Field methods for measurement of fluvial sediment: U.S. Geological Survey Open-File Report 86-531, 118 p.

Federal Highway Administration, 1993, Reconnaissance and scoping report, Colorado Forest Highway 80, Guanella Pass road, Pike and Arapaho National Forests, Park and Clear Creek Counties: Denver, Federal Highway Administration, Central Federal Lands Highway Division, 88 p.

Fishman, M.J., 1993, Methods of analysis by the U.S. Geological Survey National Water Quality
Laboratory-Determination of inorganic and organic constituents in water and fluvial sediments: U.S. Geological Survey Open-File Report 93-125, $217 \mathrm{p}$.

Fishman, M.J., and Friedman, L.C., eds., 1989, Methods for determination of inorganic substances in water and fluvial sediments (3d ed.): U.S. Geological Survey Techniques of Water-Resources Investigations, book 5, chap. A1, 545 p.

Fishman, M.J., Raese, J.W., Gerlitz, C.N., and Husband, R.A., 1994, U.S. Geological Survey approved inorganic and organic methods for the analysis of water and fluvial sediment, 1954-94: U.S. Geological Survey Open-File Report 94-351, 55 p.

Klemm, D.J., Lewis, P.A., Fulk, F., and Lazorchak, J.M., 1990, Macroinvertebrate field and laboratory methods for evaluating the biological integrity of surface waters: Environmental Protection Agency, EPA/600/4-90/030, 256 p.

Lange-Bertalot, H., 1979, Pollution tolerance of diatoms as a criterion for water quality estimation: Nova Hedwigia, v. 64, p. 285-304.

Merritt, R.W., and Cummins, K.W., 1996, An introduction to the aquatic insects of North America: Dubuque, Iowa, Kendall/Hunt Publishing Co., 862 p.

Metzmeier, L., 1994, Use of a diatom bioassessment index for water quality assessment in Kentucky: Orlando, Florida, North American Benthological Society meeting, $17 \mathrm{p}$.

Pennak, R.W., 1989, Fresh-water invertebrates of the United States (3d ed.): New York, J. Wiley and Sons, Inc., $628 \mathrm{p}$.

Plafkin, J.L., Barbour, M.T., Porter, K.D., Gross, S.K., and Hughes, R.M., 1989, Rapid Bioassessment Protocols for use in stream and rivers, benthic macroinvertebrates and fish: Washington, D.C., U.S. Environmental Protection Agency, Office of Water, EPA/444/4-89-001, variously paged.

Porter, S.D., Cuffney, T.F., Gurtz, M.E., and Meador, M.R., 1993, Methods for collecting algal samples as part of the National Water-Quality Assessment Program: U.S. Geological Survey Open-File Report 93-409, 39 p.

Rosenberg, D.M., and Resh, V.H., 1993, Freshwater biomonitoring and benthic macroinvertebrates: New York, Chapman and Hall, 488 p.

Stevenson, R.J., Bothwell, M.L., and Lowe, R.L., 1996, Algal ecology-Freshwater benthic ecosystems: San Diego, California, Academic Press, Inc., 753 p.

Stewart, K.W., and Stark, B.P., 1988, The nymphs of North American stonefly genera (Plecoptera): Hyattsville, Maryland, Entomological Society of America, 460 p.

Thorp, J.H., and Covich, A.P., 1991, Ecology and classification of North American freshwater invertebrates: San Diego, California, Academic Press, Inc., 911 p. 
Tweto, Ogden, comp., 1979, Geologic map of Colorado: U.S. Geological Survey State Geologic Map, scale 1:500,000.

Van Dam, H., Mertens, A., and Sinkeldam, J., 1994, A coded checklist and ecological indicator values of freshwater diatoms from the Netherlands: Netherlands Journal of Aquatic Ecology, v. 28, no. 1, p. 117-133.

Ward, J.R., and Harr, C.A., eds., 1990, Methods for collection and processing of surface-water and bed-material samples for physical and chemical analyses: U.S. Geological Survey Open-File Report 90-140, 71 p.

Ward, J.V., and Kondratieff, B.C., 1992, An illustrated guide to the mountain stream insects of Colorado: Niwot, Colorado, University Press of Colorado, $191 \mathrm{p}$.

Waters, T.F., 1995, Sediment in streams-Sources, biological effects, and control: Bethesda, Maryland, American Fisheries Society Monograph 7, 251 p.
Wershaw, R.L., Fishman, M.J., Grabbe, R.R., and Lowe, L.E., eds., 1987, Methods for determination of organic substances in water and fluvial sediments: U.S. Geological Survey Techniques of Water-Resources Investigations, book 5, chap. A3, 80 p.

Wiggins, G.B., 1996, Larvae of the North American caddisfly genera (Trichoptera): Toronto, Canada, University of Toronto Press, $457 \mathrm{p}$.

Winters, D.S., Gallagher, J.P., and McMartin, L., 1993, Basin-wide stream habitat inventory for the Geneva Creek watershed: United States Department of Agriculture, Forest Service, Pike and San Isabel National Forest, Supervisor's Office Fisheries Staff Report, $27 \mathrm{p}$.

Wolman, M.G., 1954, A method for sampling coarse riverbed material: Transactions of the American Geophysical Union, v. 35, p. 951-956. 


\section{MACROINVERTEBRATE AND PERIPHYTON DATA}


